\title{
A CONSPECTUS OF THE NATIVE AND NATURALIZED SPECIES OF NEPHROLEPIS (NEPHROLEPIDACEAE) IN THE WORLD
}

\author{
P.H. HOVENKAMP ${ }^{1} \&$ F. MIYAMOTO ${ }^{2}$
}

SUMMARY

\begin{abstract}
All species of the genus Nephrolepis are reviewed and described. 19 species are recognized, with 3 varieties, and 7 putative or confirmed hybrids are briefly discussed. Two new combinations are made, of which one as the result of a transferral of species to varietal rank. One variety and two hybrids are described as new. A change of name is proposed for the commonly recognized $N$. falcata and $N$. multiflora.
\end{abstract}

Key word: Nephrolepis.

\section{HISTORY OF THE GENUS}

The genus Nephrolepis was established by Schott (1834) to accommodate a number of species until then included in Aspidium, Nephrodium and Polypodium, which he distinguished on the basis of the venation pattern and soral position. The genus was quickly adopted by Presl (1836), who further diagnosed it by the presence of articulate pinnae. Presl added a number of species (including a few now no longer included in Nephrolepis), and erected the genus Leptopleuria for N. abrupta, a taxon with an aberrant soral position. The articulated pinnae were accepted as characteristic for the genus by Smith $(1841,1842 \mathrm{a})$, who also recognized the correct affinity of N. abrupta. The modern circumscription of Nephrolepis was attained when Smith (1857, 1866, 1875) distinguished both Nephrolepis and Arthropteris in the modern sense, using the differences in articulation and the stoloniferous habit of Nephrolepis as generic characters. Hooker (1862), characteristically, immediately confused the issue by including Arthropteris palisotii (with the misapplied name $N$. obliterata) as a species "peculiar in the genus". Hooker (1862) also introduced the notion that N. exaltata is a pantropical species, thus laying the groundwork for later misconceptions that Nephrolepis is a particularly difficult genus expressed by, e.g., Copeland (1947).

In the modern circumscription, Nephrolepis is accepted in most recent floristic and horticultural accounts, e.g., Proctor (1989), Nauman (1992), Hoshizaki \& Moran (2001), Mickel \& Smith (2004). Current interest in Nephrolepis derives to a large extent from its popularity as a cultivated plant since the early 20th century (Benedict, 1915). Nevertheless, there have been no published revisions of Nephrolepis on a worldwide

1) Nationaal Herbarium Nederland, Universiteit Leiden branch, P.O. Box 9514, 2300 RA Leiden, The Netherlands.

2) Department of Agriculture, Tokyo University of Agriculture, 1737 Funako, Atsugi city, Kanagawa Pref., 243-0034, Japan. 
scale. The American taxa have been revised by Nauman (1985) and the Malesian taxa by Hovenkamp (in prep.), while revisional work by Miyamoto has remained unpublished. In this conspectus we bring together data from Hovenkamp and Miyamoto, together with data from Nauman (for which we are indebted to E.O. Schilling for making a copy of Nauman's thesis available).

\section{Morphology and characters}

The morphology of Nephrolepis has been studied extensively and in great detail (Heinricher, 1907; Sen \& Sen, 1973; Espagnac, 1973; Nayar \& Bajpai, 1978).

\section{Rhizome}

The rhizome system is composed of two different elements: erect, rootless frondbearing parts and creeping, root-bearing runners. The frond-bearing parts in all Malesian species form well-developed, erect, sometimes aerial trunks, bearing several green fronds at the same time (trunks are poorly developed or virtually absent only in species outside the area). Runners originate from the frond-bearing part, and may be variously developed and branched. Although the morphology of the runners is clearly of a rhizomatous nature, during development of a plant runners and roots appear to be equivalent (Espagnac, 1973). The vascular system of the erect part is a dictyostele, while of the runners it is protostelic. In some species further modifications of the runners occur. In N. cordifolia (and related non-Malesian taxa) underground tubers may be formed, which are irregularly globose to somewhat elongated, up to a few $\mathrm{cm}$ in diameter and densely scaly, from the tubers, new plantlets can be formed, and also in times of drought, the water reserve in the tubers can be used. In some species (most notably in N. hirsutula and N. brownii) the parts of the runners close to the erect rhizomes are often stout and stilt-like, propping up the frond-bearing erect stems. In $N$. radicans, the runners are distinctly differentiated. Most conspicuous are the negatively geotropic runners that are thick and scrambling and may form dense thickets. They bear erect frond-bearing branches at more or less regular intervals, from which thin, twining, tendril-like and rootless runners originate, as well as positively geotropic runners that are distinctly thinner than the scrambling ones, and bear roots at the tips or wherever they come into contact with a suitable substrate. In N. acutifolia the parts close to the erect rhizomes are frequently branched, forming bush-like structures around the tufts of fronds. The degree to which otherwise unmodified runners bear young plantlets varies, and is highest in $N$. lauterbachii, where young plantlets are often regularly spaced on horizontal runners. The runners, which may reach lengths of several metres, develop into frond-bearing stems when they are severed form the main plant, thus facilitating colonization and vegetative propagation.

\section{Scales}

Scales are most densely set on the rhizome and the basal parts of the stipe, more sparsely on runners and stipes, and in most species very sparse or absent on the lamina of mature fronds. The rhizome scales are usually very similar to the basal scales on the stipe (Plate 1), whereas distinctly different scales occur higher up on the stipe and on the lamina. We will use the term 'basal scales' to distinguish the scales occurring on rhizome and stipe base from the scales on the upper part of the stipe and rachis. The central part of the basal scales is in several species conspicuously dark and appressed 

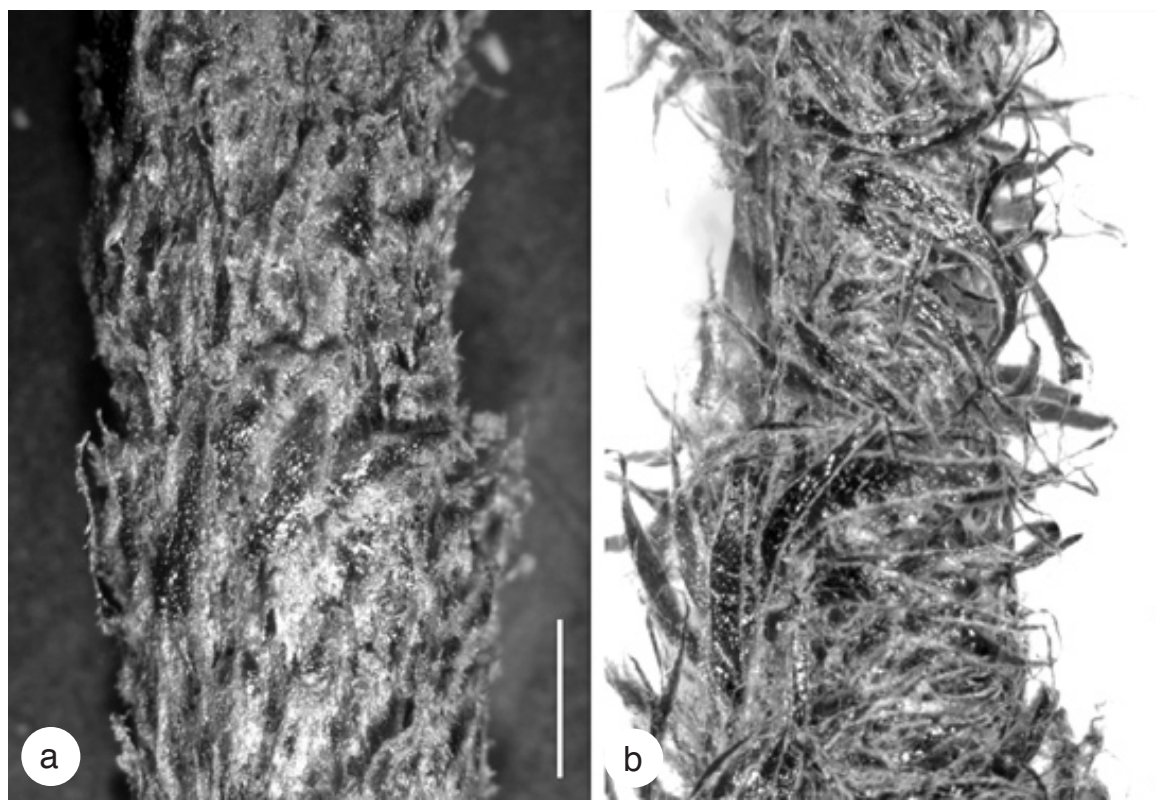

Plate 1. a. Nephrolepis brownii (Desv.) Hovenkamp \& Miyam., basal scales on stipe appressed; b. N. biserrata (Sw.) Schott, basal scales on stipe spreading sideways (a: Hortus Leiden 20000574; b: Croft 62, L). - Scale bar: $1 \mathrm{~mm}$.

(Plate 1a), with the margin fringed with teeth or longer hairs. In other species, the scales are more evenly brown to straw coloured, in which case they are usually also more spreading (Plate 1b). The scales on the upper part of the stipe are often strikingly different, and in some cases an accurate identification may be impossible without the presence of basal scales. Scales on the rachis (Plate 2) usually are similar to the upper stipe scales but smaller, and may be more highly dissected. An unusual property of the rachis scales is that the acumen of the scale is often directed towards the base of the frond, not towards the apex as it is on the rhizome and stipe base. The scales on the runners are usually much sparser than on the frond-bearing parts and mostly light brown.

\section{Fronds}

Above the stipe, the lamina is in outline usually strongly elongated and strap-shaped. As terminal growth usually appears to have been arrested before a well-formed apex develops, the length of the fronds is to some degree indeterminate, and most fronds are never completely unrolled. However, both field observations and cultivated specimens indicate that fronds are not able to grow indeterminately (there appears to be a maximum length of a few metres for fully grown fronds of $N$. biserrata), but the highly exposed and sensitive apex is apparently very sensitive to adverse conditions so that presumably even short spells of such conditions can cause the arrest of apical growth. At the base, the lamina is reduced to various degrees, the lowermost pinnae usually at wider distances from each other than higher upwards. The articulation of the pinnae 

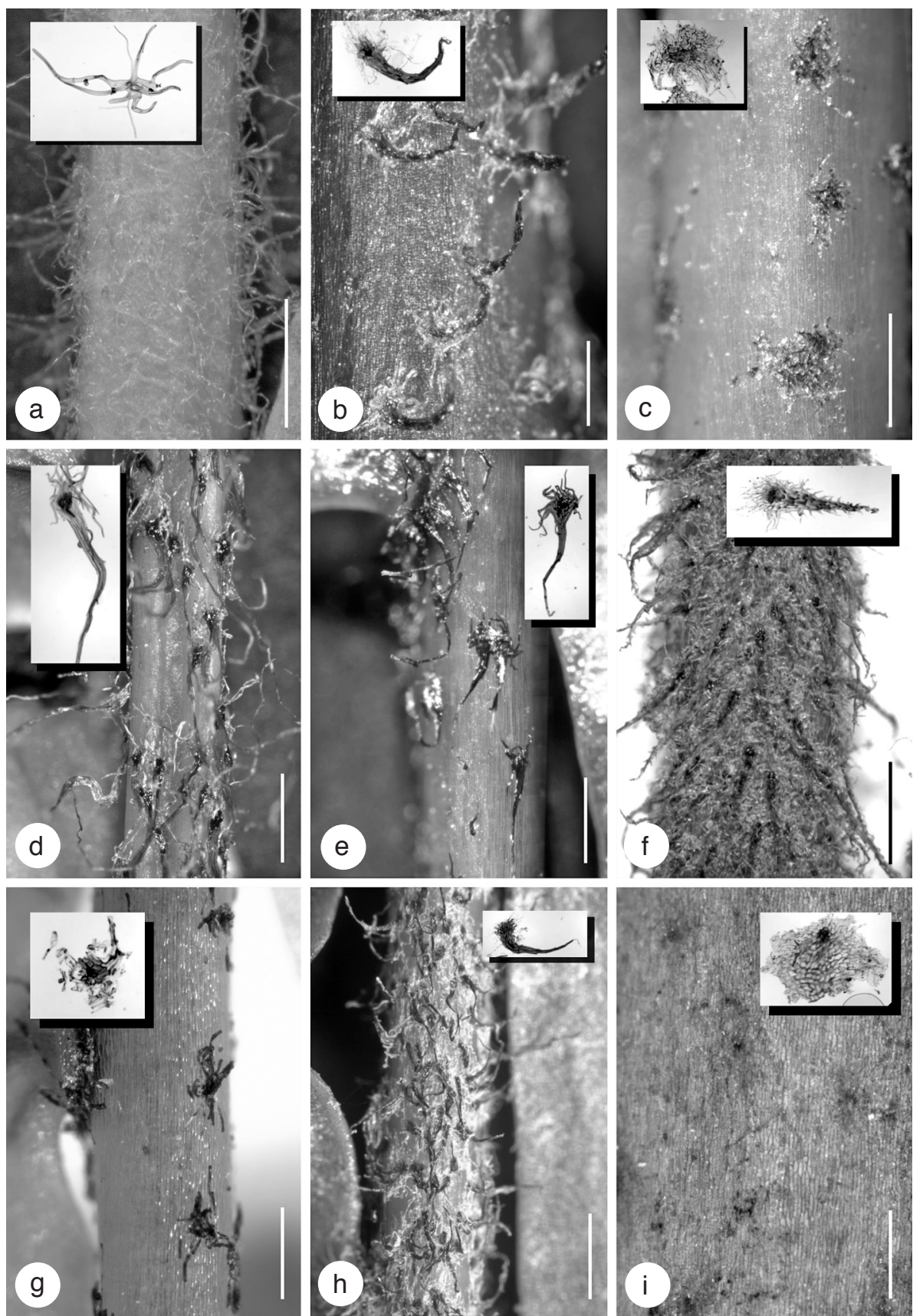
$\leftarrow$

Plate 2. a. Nephrolepis acutifolia (Desv.) H. Christ, rachis scales tomentose; b. N. davallioides (Sw.) Kunze, rachis scales with dark apex, directed sideways; c. N. radicans (Burm. ) Kuhn, rachis scales without protracted acumen, appressed; d. N. cordifolia (L.) C. Presl var. cordifolia, rachis scales with elongated acumen; e. $N$. lauterbachii $\mathrm{H}$. Christ, rachis scales with elongated, dark acumen; f. N. hirsutula (G. Forst. ) C. Presl, rachis scales dense, strongly dentate; g. N. falciformis J. Sm., rachis scales without protracted acumen, dark; h. N. falcata (Cav.) C. Chr., rachis scales very dark, directed sideways; i. N. obliterata (R.Br. ) J. Sm., rachis scales appressed, very inconspicuous (a: Anderson 3632, L, inset: Nur 204, L; b: Hortus Leiden, inset: Stone 6075, L; c: Hortus Leiden, inset: Alston 13116, L; d: Hortus Leiden 960313, inset: Van Beusekom \& Phengkhlai 3094, L; e: Hortus Leiden 930105, inset: Vink \& Schram BW 8623, L; f: Pullen 7584, L, inset: Idjan \& Mochtar 917, L; g: Hortus Leiden 960312, inset: De Joncheere 1329, L; h: Hortus Leiden 902014; inset: Elmer 10330, P; i Takeuchi 8915, L, inset: Van Royen 3170, L). - Scale bars: a-c, e, g = 1 mm; d, f, h = $2 \mathrm{~mm}$; i $=0.5 \mathrm{~mm}$.

is often highly functional, and pinnae are often absent from older fronds (as well as from many herbarium specimens). Indument: hairs may be present regularly on the upper surface of the main rachis and pinna rachis, but also to varying degrees on both sides of the lamina. In some species, hairiness is more frequent than in others, but it is not possible to evaluate to what degree the presence of hairs is also decided by stage in the life-cycle of a plant.

Sori

Sori vary from reniform to lunulate or linear, and may also be cup-shaped (Fig. 1). Reniform sori, occurring in the majority of species, may differ in the degree to which the sinus is narrowed. When the sinus is very narrow, the sori may appear to be fully peltate when dry. Lunulate sori, occurring in $N$. auriculata and related taxa are attached with a longer, often concave base. They often open more towards the apex of the pinnae. Sori with a straight or somewhat convex base occur in N. abrupta and $N$. rosenstockii, situated close to and opening towards the margin. In N. acutifolia, the sori are linear (sometimes interrupted). Cup-shaped sori, attached on base and sides, occur in a marginal position in N. davalliae.

\section{Spores}

Spore morphology of the Asian species has been studied by Liew (1977) and Tryon $\&$ Lugardon (1991). Spores are relatively small (27-35 $\mu \mathrm{m}$, rarely to $39 \mu \mathrm{m}$ long), monolete and elongate in outline. The exospore is smooth or weakly sculptured, and the contours of the spore wall are derived from the variably thick perispore only. In the perispore sculpture, three distinct character states can be distinguished: coarsely rugate-tuberculate, more finely verrucose, and longitudinally rugate.

Coarsely rugate-tuberculate spores occur in the majority of species. Spores with this character have tubercles of varying degree of dispersion, which may be fused into irregular ridges, but the degree to which the tubercles or rugae are distinct and prominent may vary even within a species. The size of the individual tubercles or the corresponding width of the ridges varies between 2 and $2.5 \mu \mathrm{m}$. In the finely verrucose type the individual tubercles are smaller (mostly $1-1.5 \mu \mathrm{m}$ ), often more dispersed and less often coalescing into irregular ridges. Spores with this character occur in $N$. brownii, $N$. hirsutula and $N$. radicans, but this character is not always clearly distinct 

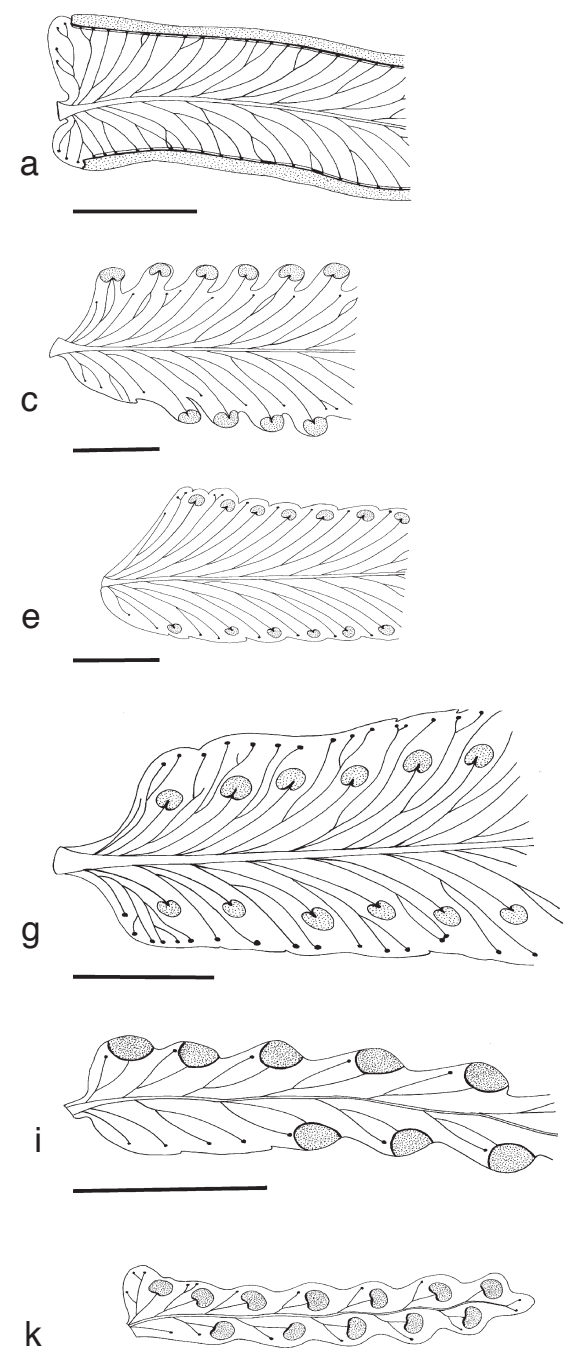

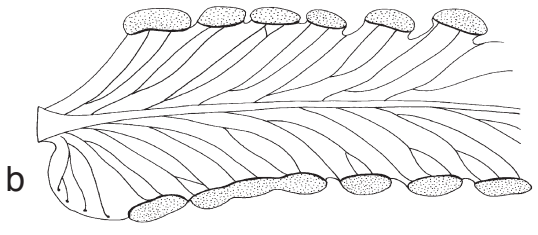

d
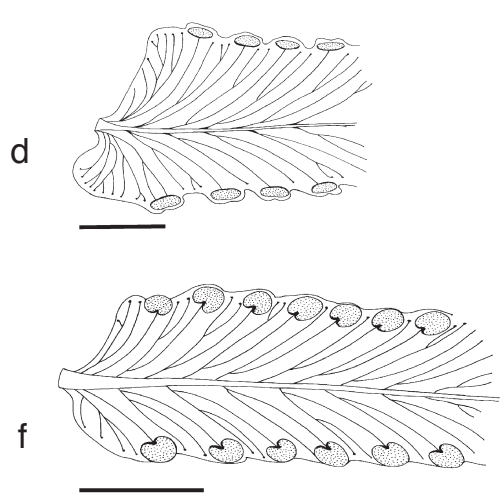

$\mathrm{h}$
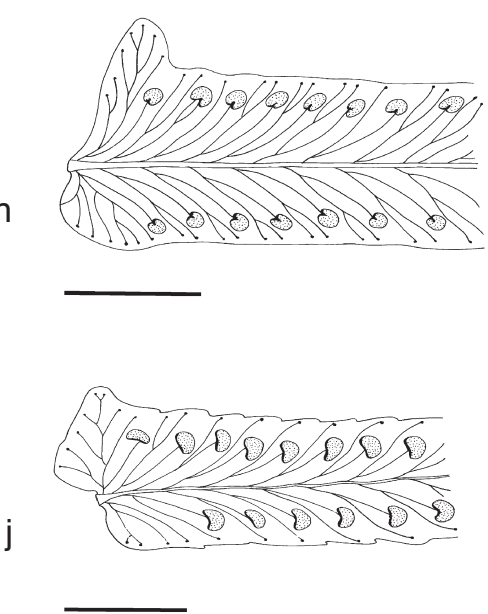

Fig. 1. a. Nephrolepis acutifolia (Desv.) H. Christ, sorus marginal, uninterrupted; b. N. dicksonioides H. Christ, sori marginal, on more than one vein, mostly separate; c. N. davallioides (Sw.) Kunze, sori marginal, on separate teeth; d. N. abrupta (Bory) Mett., sori submarginal, protruding slightly; e. N. obliterata (R.Br.) J. Sm., sori submarginal, not protruding; f. N. brownii (Desv.) Hovenkamp \& Miyam., sori submarginal; g. N. biserrata (Sw.) Schott, sori submedial to medial; h. N. hirsutula (G. Forst.) C. Presl, sori submedial; i. N. davalliae Alderw., sori marginal, cup-shaped; j. N. cordifolia (L.) C. Presl var. cordifolia, sori medial, lunulate; k. N. lauterbachii H. Christ, sori medial, lunulate, pinnae sinuose, attachment one-sided (a: Surbeck 1035; b: Idjan \& Mochtar 283; c: Van Borssum Waalkes 1345; d: Kato \& Wiriadinata B 6427; e: Van Royen 3170; f: Van Ooststroom 13534; g: Raciborski s.n.; h: Kato et al. C 2082; i: Brass 13296; j: Danser 6176; k: Takeuchi 10769; all L). - Scale bars $=5 \mathrm{~mm}$. 
from the previous one. The longitudinally ridged spores have coarse rugae more or less regularly orientated in the length of the spore. They occur only in N. dicksonioides and do not show any intermediates to the other types.

\section{KARYOLOGY AND HYBRIDIZATION}

Basic chromosome number is 41 for all species investigated so far, and most species appear to contain diploids only, with additional tetraploids reported in two species (Löve et al., 1977; Tindale \& Roy, 2002): in N. hirsutula in South India (probably this record refers to N. brownii) and in N. pectinata in Jamaica. Hybridization under natural circumstances occurs occasionally (Nauman, 1979b), but is probably far less common than sometimes supposed; the rampant hybridity suggested by some authors can probably for a large part be explained by an incomplete understanding of the natural species. In cultivation, most of the variation being offered on the market is due to the occurrence of vegetative 'sports' (Benedict, 1916b) and artificial hybridization plays a minor role, if any at all.

\section{DISTRIBUTION}

The genus as well as a small number of species are pantropical, but most species have a more limited distribution in either Southeast Asia or Tropical America. Brown \& Brown (1931) state for all species of Nephrolepis that they can "reasonably be considered as aboriginally introduced" in Southeast Polynesia. If true, that would indicate a contact between the native population on Hawaii with Caribbean tribes to explain the occurrence of $N$. exaltata on Hawaii.

\section{CULTIVATION}

Various forms of Nephrolepis species are among the most popular ferns in cultivation, with most forms currently cultivated presumably derived from the American N. exaltata cv. 'bostoniensis' (Benedict, 1915, 1916a, b, 1922). Before 'bostoniensis' was discovered as a source for cultivars, cultivated forms appear to have been mostly derived from Southeast Asian species. Both N. duffii Baker, introduced from Duke of York's Island, and all forms described under N. rufescens, are derived from N. hirsutula. Despite the popularity of cultivars of $N$. exaltata, there are no indications that any of these are escaping or naturalizing on a significant scale. Nephrolepis exaltata itself is noted as an escape on a few oceanic islands probably outside its native range (Hohenester \& Wells, 1993), but does not appear to spread over larger areas, in strong contrast to N. brownii, which is naturalizing rapidly in the Americas (Nauman, 1979a, 1985; Weber, 2004).

\section{IDENTIFICATION}

Nephrolepis has the reputation of being difficult. It is certainly the case that there may be a considerable difference between newly established and mature plants and identification of juvenile plants may be difficult, especially when they are 'outliers' 
newly established from runners. Accordingly, when collecting Nephrolepis specimens it is preferable to take a single frond from a well-established clump than a small 'outlier' plant neatly fitting on a herbarium sheet in its entirety.

In a few other cases species may be part of a complex in which delimitation between the various elements is difficult, e.g. between the taxa around $N$. cordifolia ( $N$. cordifolia var. pumicicola, $N$. pectinata, $N$. undulata). However, on the whole, most species are appreciably different and identification of complete fronds of mature plants will present little difficulty in the great majority of species.

To facilitate the identifications of more fragmentary, sterile, material, the following list of 'spot characters' may be useful:

\section{Pinnae}

Attachment one-sided - lauterbachii, pectinata

Acroscopic base very conspicuously auricled - brownii, hirsutula

Base narrowed on both sides - biserrata

Basiscopic base conspicuously auricled - cordifolia, undulata

Margin deeply incised - davallioides, dicksonioides

\section{Lamina indument}

Tomentose-flocculose - acutifolia

Scaly, persistent - brownii, hirsutula

Soft-hairy - biserrata

\section{Rachis indument}

Appressed isodiametric scales - obliterata, radicans

Dense, scaly, rufous - abrupta, hirsutula

Dense, scaly, pale - brownii, cordifolia

Dense, scaly, dark - davallioides, falcata, lauterbachii

Dense, 'scabrous' - davalliae, rivularis

Sparse, inconspicuous or absent - falciformis, obliterata, pendula

Highly dissected, appearing as downy tomentum - acutifolia

\section{NEPHROLEPIS}

Nephrolepis Schott (1834) pl. 3; Backer \& Posth. (1939) 88; Copel. (1947) 90; Holttum (1968) 372; Copel. (1958) 184; Tagawa \& K. Iwats. (1985) 170; Proctor (1989) 259; Nauman (1992) 286; G.H.

Bell (1998) 440; Mickel \& A.R. Sm. (2004) 403. - Type: Nephrolepis exaltata (L.) Schott. Leptopleuria C. Presl (1836) 136, pl. 5, f. 9-11. - Type: Leptopleuria abrupta (Bory) C. Presl.

Terrestrial or epiphytic ferns, bearing basifix, pseudopeltate or peltate scales on all parts. Rhizome consisting of long creeping or pendent protostelic runners bearing roots and erect dictyostelic radial stems bearing fronds and runners. Fronds not articulated to the rhizome, stipitate, pinnate, often not forming an apical pinna or segment, scales on fronds often inconspicuous or deciduous, catenate hairs sometimes present. Pinnae articulated to the midrib, sessile, often with unequal base, margin usually crenate or serrate, apex rounded to acuminate, venation free, 1 or 2 (or 3 ) times furcate except in the most basal vein-group, free veins ending before the margin in a hydathode. 
Sori terminal on the acroscopic vein-branch (rarely innervated by 2 veins), medial to marginal, indusiate, indusium reniform to lunulate or linear, glabrous. Sporangia long-stalked, glabrous, $0.2-0.24$ by $0.15-0.18 \mathrm{~mm}$, with $(11-) 13(-16)$ indurated annulus cells. Spores 27-35(-39) $\mu \mathrm{m}$, elongate, monolete, brown, variously verrucate to tuberculate or rugose.

\section{KEY TO THE SPECIES}

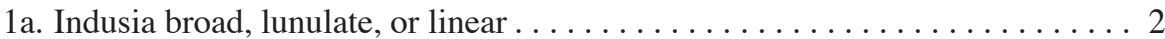

b. Indusia reniform, with wide or narrow sinuses $\ldots \ldots \ldots \ldots \ldots \ldots \ldots$

2a. Basal scales bicolorous, each with dark brown or blackish central part ..... 3

b. Basal scales concolorous, central parts straw-coloured, light brown or rufous 4

3a. Basal scales shining; rachis scales without a distinctly protracted acumen. . . . . .

16. N. pendula

b. Basal scales dull; rachis scales with a well-developed acumen. 15 . N. pectinata

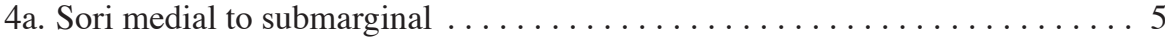

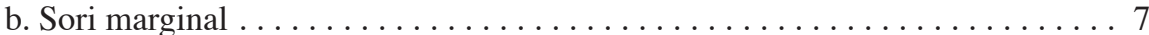

5a. Pinnae with acute apex; rachis scales hyaline . . . . . . 19. N. undulata

b. Pinnae with rounded or obtuse apex; rachis scales light brown to dark . . . . 6

6a. Rachis scales dark; pinna-base fully one-sided, basiscopically base narrowly cuneate; basal scales with entire acumen. . . . . . . . 13. N. lauterbachii

b. Rachis scales light brown; pinna-base slightly to strongly unequal, basiscopically rounded or cordate; basal scales usually with denticulate acumen . . . . . . . . .

5. N. cordifolia

7a. Sori linear; basal scales squarrose, with light brown central part 2 . N. acutifolia

b. Sori round or elongated; basal scales appressed, spreading or sometimes squarrose,

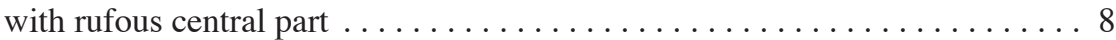

8a. Indusium attached at base and sides; basal scales dull, with microscopic marginal glands around the scale, with entire or dentate acumen; rachis scales dark, with entire or dentate acumen . . . . . . . . davalliae

b. Indusium attached at broad base; basal scales shining, without marginal glands, with ciliate or fimbriate acumen; rachis scales hyaline to rufous, with ciliate acumen 9

9a. Pinna apex acuminate to caudate; pinna margin in basal part entire . . . . . . . .

8. N. dicksonioides

b. Pinna apex rounded, obtuse or acute; pinna margin in basal part crenate . . . . . .

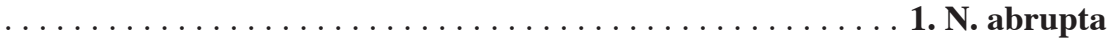

10a. Plants scrambling, runners modified into thick scrambling ones and thinner, tendril-like or root bearing ones; rachis scales distinctly bullate when dry . . . . . .

17. N. radicans

b. Plants not scrambling, runners not modified; rachis scales flat when dry . . . 11

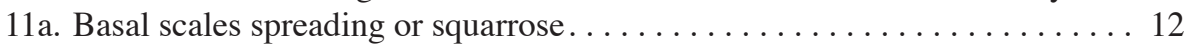

b. Basal scales appressed . . . . . . . . . . . . . . . . . 14

12a. Indusium with wide sinus; lamina base strongly reduced; basal scales dull . . . . .

9. N. exaltata

b. Indusium with narrow sinus; lamina base truncate or moderately reduced; basal

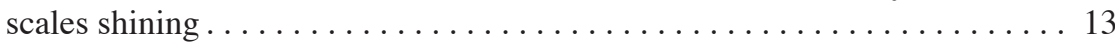


13a. Basal scales with rufous or dark brown central part; pinna-base strongly unequal; rachis scales with spreading to erect marginal appendages, giving the rachis a

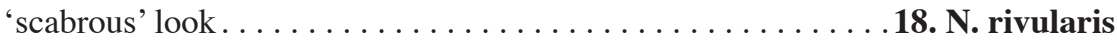

b. Basal scales with light brown central part; pinna-base equal or slightly unequal;

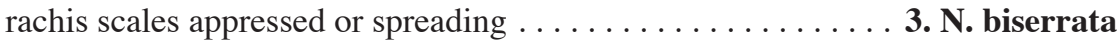

14a. Basal scales dull; rachis scales very sparse or sparse, appressed, without a distinctly protracted acumen; scales on lamina absent or sometimes present . . . . . . 15

b. Basal scales shining; rachis scales dense to very dense, spreading to squarrose, with a well-developed protracted acumen; scales on lamina usually persistent 16

15a. Rachis scales very sparse, inconspicuous, hyaline; pinnae not auricled; sori mar-

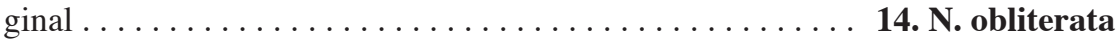

b. Rachis scales sparse, dark and conspicuous when present; pinnae slightly to dis-

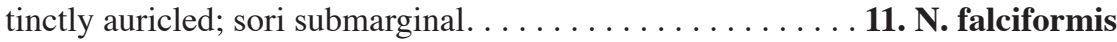

16a. Sterile pinnae strongly auricled; basal scales with distinct, wide hyaline margin

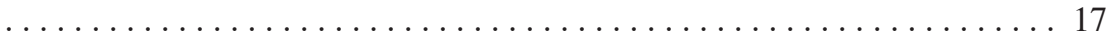

b. Sterile pinnae auricled or not; basal scales with hyaline margin narrow or present

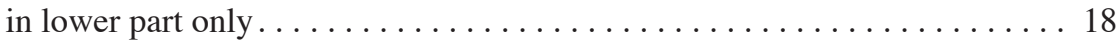

17a. Hairs on upper side of costae absent; rachis scales rufous, with strongly dentate

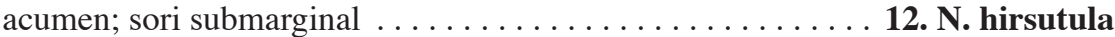

b. Hairs on upper side of costa present; rachis scales hyaline or light brown (rarely rufous), with nearly entire acumen; sori submedial. . . . . 4. N. brownii

18a. Rachis scales dark, with entire acumen; lamina base strongly reduced; pinna-base strongly unequal, acroscopically truncate, slightly to distinctly auricled; sori sub-

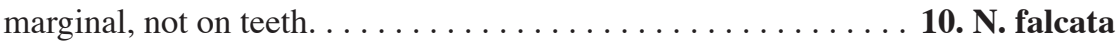

b. Rachis scales hyaline or with a dark, acicular, often ciliate acumen; lamina base truncate; pinna-base slightly unequal, acroscopically emarginate to cuneate, not auricled; sori marginal, often on separate teeth . . . . . . . 7. N. davallioides

\section{Nephrolepis abrupta (Bory) Mett. - Map 1}

Nephrolepis abrupta (Bory) Mett. (1856) 99; J. Sm. (1875) 227. - Dicksonia abrupta Bory (1804) 187, pl. 30. - Leptopleuria abrupta (Bory) C. Presl (1836) 137, pl. 5, f. 9-11. - Type: Anon. s.n., s.d. (K, L, P), Réunion.

Habit, rhizome morphology. Runners 1-2 mm thick, branching angle divaricate. Scales on runners dense, spreading or squarrose. Tubers absent. Fronds to $200 \mathrm{~cm}$ long (or much longer), $15-19 \mathrm{~cm}$ wide, stipe $30-35 \mathrm{~cm}$ long. Lamina base strongly reduced, tapering over $20-60 \mathrm{~cm}$, basal pinnae $1-1.2 \mathrm{~cm}$ long, $2.5-6 \mathrm{~cm}$ distant, middle pinnae slightly to strongly falcate (mostly the cauda only is falcate). Sterile pinnae 3-13 by $0.8-2.8 \mathrm{~cm}$ (usually distinctly triangular, narrowed gradually from base to apex), leathery, base strongly unequal, basiscopic base cordate (strongly, sometimes somewhat auriculate), acroscopic base cuneate, truncate, rounded or cordate (always less distinctly cordate than the basiscopic base), not or slightly auricled (usually distinctly dilated, but not auricled), margin in basal part finely crenate, towards apex crenate, apex rounded, obtuse or acute. Fertile pinnae $3.2-14$ by $0.7-1.8 \mathrm{~cm}$, differing from sterile pinnae in the margin being incised between sori but not beyond the attachment. Indument. Basal scales pseudopeltate, spreading, 5.5 by $1 \mathrm{~mm}$, central part rufous, shining (translucent), 


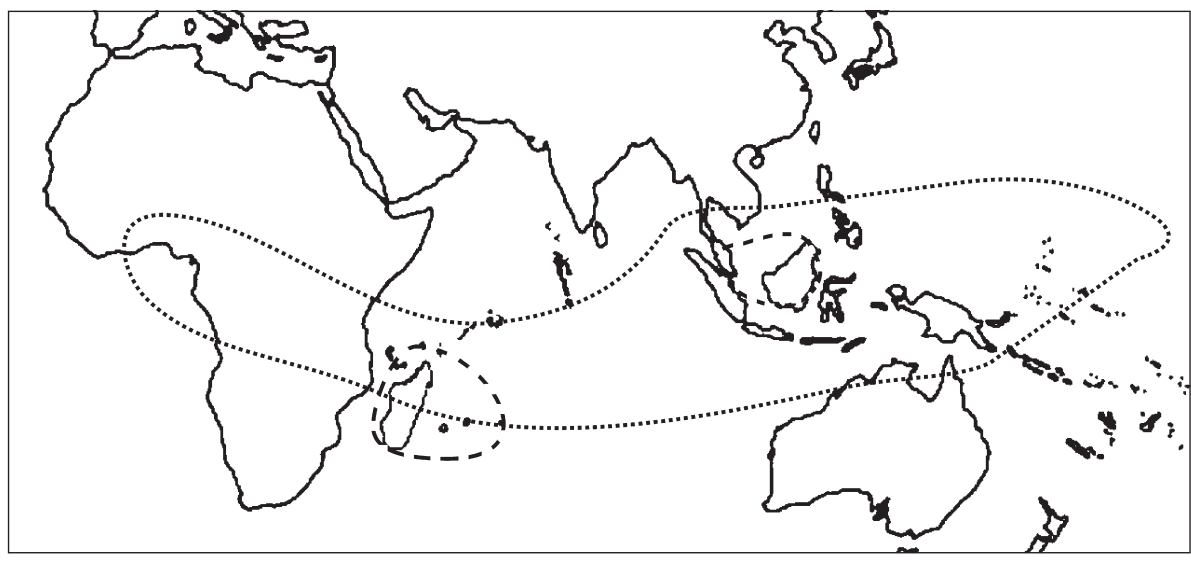

Map 1. Distribution of Nephrolepis abrupta (Bory) Mett. (broken line) and N. acutifolia (Desv.) H. Christ (dotted line).

hyaline margin absent, marginal glands absent, margin in basal part fimbriate, acumen fimbriate, transition to rachis scales abrupt or basal scales persisting to high up. Rachis scales sparse or dense, with a well-developed protracted ciliate acumen, appressed or spreading, light brown or rufous. Scales on lamina absent. Hairs on lamina absent or present, short, dense. Sori marginal, 14-34 pairs on fully fertile pinnae, elongated, not impressed. Indusium broad, attached at broad base.

Distribution - Indian Ocean: Madagascar, Comores, Réunion; Malesia: Malay Peninsula, Borneo.

Habitat \& Ecology - Lowlands to $800 \mathrm{~m}$, often in pioneer vegetation on recent lava flows, also in degraded forest, in the eastern part of the range usually terrestrial, on limestone, sometimes epiphytic.

Note - Nephrolepis abrupta is somewhat similar to N. dicksonioides and has been confused with that species, from which it differs in more triangular pinnae, gradually narrowed from the base towards the apex, the fertile pinnae not incised beyond the sori, so that the sori are protruding from the margin, not on distinct teeth, indusium not reaching margin, innervated by 1 , rarely 2 veins, rachis scales more strongly lacerated. The pinnae often appear to stand in a plane at right angles to the rachis. They are usually glabrous, but may be densely short-hairy all over the lamina, with hairy and glabrous fronds sometimes occurring on the same plant. Plants from the eastern part of the range are often larger than those from the western part, which are, especially those from the Comores, often compact and densely scaly in the lower part of the lamina. The more compact habit of these plants is not preserved in cultivation.

\section{Nephrolepis acutifolia (Desv.) H. Christ - Fig. 1a; Map 1; Plate 2a}

Nephrolepis acutifolia (Desv.) H. Christ (1895) 243; Backer \& Posth. (1939) 89; Copel. (1958) 189; Holttum (1968) 375; Tagawa \& K. Iwats. (1985) 171; Verdc. (2001) 8. — Lindsaya acutifolia Desv. (1827) 312. - Type: Anon. s.n. (P? not found), Mascarenes.

Isoloma lanuginosa J. Sm. (1842b) pl. 102. - Lindsaya lanuginosa (J. Sm.) Hook. (1846) 210.

- Type: Wallich 154 (BM, K), East Indies. 
Nephrolepis lindsayae H. Christ (1898) 837. - Type: Schneider s.n. (P), Sumatra.

Nephrolepis niphoboloides Alderw. (1913) 18. - Type: Koorders 61 (BO), Java.

Nephrolepis marginalis Copel. (1917) 49. - Type: Topping 1632 (n.v.), Borneo.

Diellia browni E.D. Br. \& F. Br. (1931) 46, t. 7. - Type: Brown 347 (BISH n.v.), Hivaoa.

Habit, rhizome morphology. Plants forming tufts of 4-8 fronds. Runners densely branching at \pm right angles, forming 'bushes' around the base of the plants, $1-3 \mathrm{~mm}$ thick (distinctly tapering to thinner ends). Scales on runners dense (especially at the base), spreading to squarrose. Tubers absent. Fronds $150 \mathrm{~cm}$ long or more to $15 \mathrm{~cm}$ wide, stipe $15-18 \mathrm{~cm}$ long. Lamina base strongly reduced, tapering over $50 \mathrm{~cm}$ or more, basal pinnae $0.6-1 \mathrm{~cm}$ long, 3-3.5 cm distant, middle pinnae straight or slightly falcate. Sterile pinnae $6-8$ by $1.5-1.9 \mathrm{~cm}$, base slightly to strongly unequal, basiscopic base truncate, rounded or cordate, acroscopic base truncate, not auricled, margin in basal part entire, apex acute. Fertile pinnae $6-7$ by $0.8-1.1 \mathrm{~cm}$, different from sterile pinnae somewhat auricled as acroscopic base. Indument. Basal scales basifix or pseudopeltate, squarrose to reflexed, often inserted on a short spine, 3.5 by $0.5 \mathrm{~mm}$, central part light brown, dull, hyaline margin absent, marginal glands present around the scale, margin in basal part ciliate, acumen dentate (teeth often unicellular), apex uniseriate, often somewhat zigzag. Rachis scales dense, often caducous, with a well-developed protracted acumen, spreading, hyaline or light brown, acumen ciliate, without a distinct central lamina, forming a floccose cover. Scales on lamina usually persistent, forming a tomentum similar to that on rachis. Hairs on lamina absent, costa absent. Sori marginal, linear (sometimes interrupted), not impressed. Indusium linear, attached at broad base.

Distribution - Africa (Madagascar to Ivory Coast) to Indochina (Burma, Thailand), Australia and the Pacific (Solomon Isl., Marshall Isl., Samoa, Guam, Caroline Isl.: Ponape).

Habitat \& Ecology - At low elevations (sea level up to $200 \mathrm{~m}$ ). Usually epiphytic, often in coastal vegetation (on mangroves), also on oil palms, coconut trees, and on cliff faces.

Notes - The runners in this species are strongly branched around the erect rhizomes, with branches at angles of $60-90^{\circ}$ forming a dense bush around the rhizome. Otherwise, the marginal, elongated sori and the tomentose indument make this an easy species to recognize.

A form is widespread in Polynesia in which the sori are 'dissolved' into a series of separate sori on some fronds. The separate sori are lunular, with a wide sinus, but all directed towards the nearby margin, not to the apex as in N. cordifolia. In all other characters this form is identical to typical N. acutifolia. This form has been described as Diellia brownii on basis of the superficial resemblance of these sori to those in Diellia (which is otherwise completely unrelated).

\section{Nephrolepis biserrata (Sw.) Schott - Fig. 1g; Map 2; Plate 1b}

Nephrolepis biserrata (Sw.) Schott (1834) ad. Pl. 3; Brack. (1854) 213; Merr. (1918) 43; Backer \& Posth. (1939) 92; Copel. (1958) 187; Holttum (1968) 380; Tagawa \& K. Iwats. (1985) 175; Proctor (1989) 265; Nauman (1992) 286; Verdc. (2001) 3; Mickel \& A.R. Sm. (2004) 404. Aspidium biserratum (Sw.) Sw. (1801) 32; (1806) 46. - Hypopeltis biserrata (Sw.) Bory (1833) 65. - Lepidonevron biserratum (Sw.) Fée (1852) 301. - Nephrodium biserratum (Sw.) Desv. (1827) 253; C. Presl (1830) 31. - Type: Groendal s.n. (S n.v.), Mauritius. 
Tectaria fraxinea Cav. (1801) 250. - Type: Nee s.n. (BM, fragm., MA), Philippines.

Aspidium acutum Schkuhr (1804) 32, t. 31; Sw. (1806) 46. - Nephrodium acutum (Schkuhr) C. Presl (1830) 31. - Hypopeltis palmoides (Schkuhr) Bory (1833) 50 (nom. superfl.). - Nephrolepis acuta (Schkuhr) C. Presl (1836) 79; Baker (1867) 301. - Type: Schkuhr (1804) 32, t. 31.

Aspidium ensifolium Schkuhr (1804) 32, t. 32; Sw. (1806) 46; Blume (1828) add. et emend. - Nephrolepis ensifolia (Schkuhr) C. Presl (1836) 79. - Type: Schkuhr (1804) 32, t. 32.

Polypodium punctulatum Poir. (1804) 533. - Nephrolepis punctulata (Poir) C. Presl (1836) 79, pl. 2. - Type: Sonnerat s.n. (P-Lamarck n.v.), Martinique.

Aspidium punctulatum Sw. (1806) 46. - Lepidonevron punctulatum (Sw.) Fée (1852) 301; (1866) 87. - Nephrodium punctulatum (Sw.) Desv. (1827) 253. - Type: Plumier, Fil. p. 98, pl. 112.

Aspidium splendens Willd. (1810) 220; Blume (1828) 147. - Nephrolepis splendens (Willd.) C. Presl (1836) 79; Brack. (1854) 212; J. Sm. (1875) 227. - Type: D. Klein (Willdenow herb. 19740, B), Ceylon.

Aspidium acuminatum Willd. (1810) 221. - Nephrodium acuminatum (Willd.) C. Presl (1830) 31. - Nephrolepis acuminata (Willd.) C. Presl (1836) 79 (non Kuhn 1869). - Lepidonevron acuminatum (Willd.) Fée (1852) 301. - Type: Fluegge s.n. (Willdenow herb. 19741, B), America.

Aspidium gibbosum Willd. (1810) 222. - Nephrodium gibbosum (Willd.) Gaudich. (1828) 338. - Nephrolepis gibbosa (Willd.) C. Presl (1836) 79. - Type: Nee ? s.n. (Willdenow herb. 19743, B). Aspidium paraense Willd. (1810) 228. - Nephrolepis paraensis (Willd.) C. Presl (1836) 79. - Type: Hoffmansegg s.n. (Willdenow herb. 19752, B).

Nephrodium rufescens Schrad. (1824) 896. - Aspidium rufescens (Schrad.) Kunze (1839b) 34. - Lepidonevron rufescens (Schrad.) Fée (1852) 301; (1866) 87. - Nephrolepis rufescens (Schrad.) Wawra (1866) 200, t. 201. - Type: Anon. s.n. (herb. Mart., BR), locality unknown.

Aspidium paludosum Raddi (1825) 29, t. 44 (non Blume 1828 nec Mett. 1858). - Type: Raddi s.n. (K).

Aspidium bidentatum Spreng. (1827) 99. - Lepidonevron bidentatum (Spreng.) Fée (1852) 301.

- Nephrodium bidentatum (Spreng.) C. Presl (1830) 32. - Nephrolepis bidentata (Spreng.)

C. Presl (1836) 79. - Type: Haenke s.n. (PRC), Marianas.

Nephrodium timoriense Desv. (1827) 253. - Type: Anon. s.n. (P).

Polypodium palmoides Bory (1833) 50. - Type: Bélanger s.n. (P), Java.

Hypopeltis amygdalina Bory (1833) 64. - Type: Bélanger s.n. (P), Java.

Polypodium flagelliferum Roxb. (1844) 487. - Type: Anon. s.n. (BR), locality unknown.

Nephrolepis depauperata de Vriese (1846) 9. - Type: Reinwardt 1680 (L), Java.

Nephrolepis zollingeriana de Vriese (1846) 10. - Type: Zollinger 146 (L).

Nephrolepis platyotis Kunze (1850) 268, 312. - Type: Anon. s.n., cult. Hortus Lips. (n.v.).

Nephrolepis macrophylla C. Presl (1851) 43. - Type: Cuming 22 (BM, PRC), Philippines.

Lepidonevron biauritum Fée (1852) 301. - Nephrolepis biaurita (Fée) C. Presl (1851) 43. - Type: Hilsenberg s.n. (herb. Sieber 297) (BM, G, K), Mauritius.

Nephrolepis acuta (Schkuhr) C. Presl var. laurifolia H. Christ (1897) 355. - Nephrolepis laurifolia

(H. Christ) Proctor (1989) 262. - Lectotype (Proctor (1989) 262): Reinecke 1-d (B? n.v.; iso L).

Nephrolepis persicifolia H. Christ (1909a) 159. - Type: Versteeg 1017 (BO, K, L, P), New Guinea.

Nephrolepis caudata H. Christ (1909b) 27. - Type: Pynaert 1027 (BR, photo BM), Congo.

Nephrolepis pilosula Alderw. (1913) 18. - Type: Amdjah 542 (BO).

Pteris signata Merr. (1918) 43. - Type: unknown.

Nephrolepis dayakorum Bonap. (1918) 399. - Type: Native collector? 70 (BM, fragm., P), Borneo. Nephrolepis mollis Rosenst. (1925) 13. - Type: Brade \& Brade 141 (NY, S, UC), Costa Rica.

Habit, rhizome morphology. Plants forming tufts of 3-5 fronds. Runners 1-2.5 mm thick, branching angle divaricate. Scales on runners very sparse to dense, spreading or squarrose. Tubers absent. Fronds $120-160$ by $19-25 \mathrm{~cm}$, stipe $29-42 \mathrm{~cm}$ long. Lamina base truncate, tapering over $40-50 \mathrm{~cm}$, basal pinnae $3.5-4 \mathrm{~cm}$ long, $4.5-5 \mathrm{~cm}$ distant, middle pinnae straight or slightly falcate (or somewhat recurved). Sterile pinnae 8-11 by $1.5-2 \mathrm{~cm}$, herbaceous, thick or leathery, base equal or slightly unequal, basiscopic base 


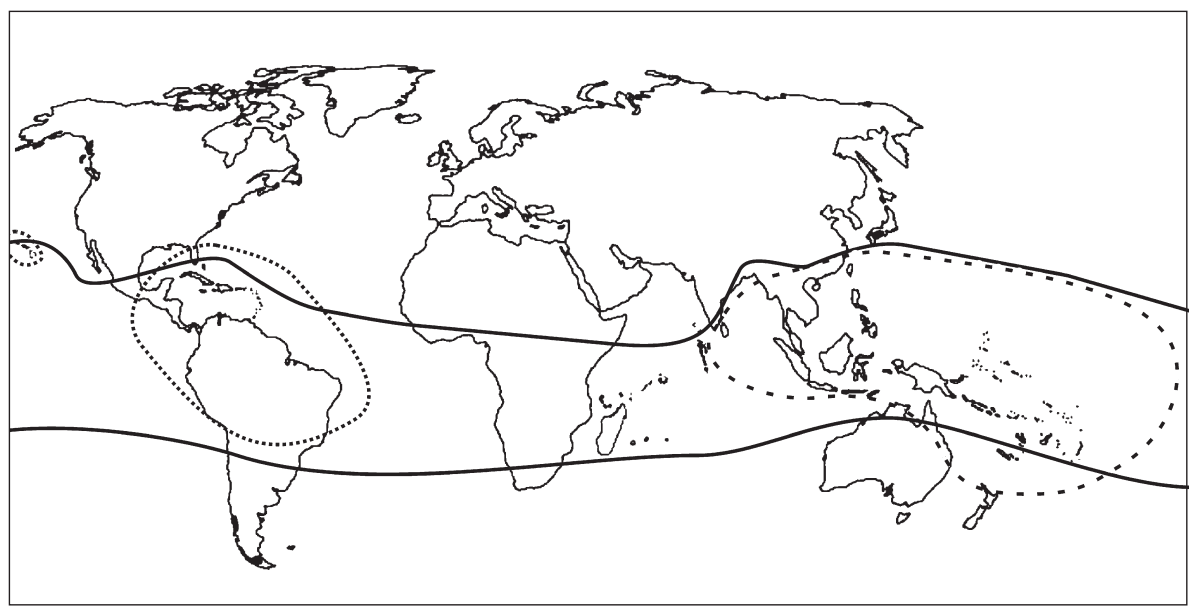

Map 2. Distribution of Nephrolepis biserrata (Sw.) Schott (continuous line) and N. brownii (Desv.) Hovenkamp \& Miyam. (broken line) (introduced = dotted lines).

cuneate, truncate or rounded, acroscopic base cuneate or truncate, slightly to distinctly auricled, margin in basal part crenate, towards apex serrate or dentate, apex obtuse, acute or acuminate. Fertile pinnae $9-15$ by $0.9-1.3 \mathrm{~cm}$, more strongly serrate than the sterile pinnae. Indument. Basal scales pseudopeltate, spreading (often somewhat falcately curved), 5 by $0.8 \mathrm{~mm}$, central part light brown, shining, hyaline margin present in lower part only, marginal glands present around the base, marginal glands small, margin in basal part fimbriate, acumen dentate, apex entire. Rachis scales sparse or dense, spreading, hyaline or light brown, with a well-developed protracted entire acumen. Scales on lamina usually persistent. Hairs on lamina absent or sometimes present, costa sometimes present. Sori submarginal or medial, 50 pairs on fully fertile pinnae, round, not impressed. Indusium reniform, with narrow sinus, attached at sinus.

Distribution - Pantropical.

Habitat \& Ecology - Usually in lowlands (sea level up to $750 \mathrm{~m}$, rarely higher, to $1500 \mathrm{~m}$ ), in open, disturbed situations, occasionally in forest; epiphytic or terrestrial. In Kalimantan reported as covering large tracts of recently burned forest.

Notes - Nephrolepis biserrata is very variable in frond size, shape of pinna-base, width of pinnae, hairiness, and to a lesser degree position of the sori. In Southeast Asia, pubescent forms occur mainly on Borneo, where they seem to be increasing as a result of recent forest fires - the burnt areas are quickly covered with a dense mat of sterile specimens of this form - and on New Guinea. Among American and African material, pubescent (sometimes densely so) specimens are common and more widespread, apparently not restricted to a narrow subrange. There may also be some size differences, with African material usually distinctly smaller than that from other locations.

Here we follow the traditional, wide circumscription of $N$. biserrata, which includes all Nephrolepis-forms with clearly inframarginal to medial sori with narrow sinus. Other rather constant characters are the basal stipe scales, which are uniformly narrow, concolorous and spread out sideways in one direction and the generally fairly large size 
of the plants. However, it is possible that in this circumscription a number of cryptic species are included. Herbarium studies may not be able to resolve these species partly for the usual reasons: lack of complete, well-documented specimens. As in many other cases, currently collected specimens appear to be collected with the aim to document the presence of known species only, not to help in distinguish unknown ones. It must be feared that the advent of fast 'biodiversity assessments' will do nothing to remedy this situation.

A very distinct form occurs on Ascension Island. In this form, the basal scales are spreading/ascending, narrow, slightly bicolorous, entire. The fronds are rather short, widest in the middle and strongly narrowed towards base, with basal pinnae reduced, often to short auricles. Pinnae are often slightly auricled acroscopically, then a little pinched and widening again to c. halfway, with obtuse to acute apex. All parts of the fronds are densely covered in hairs. The sori are closer to the margin than is typical for $N$. biserrata, and the ripe sori have inconspicuous, shrivelled indusia. An exactly similar specimen was collected on the coast of Brazil: Lindeman 6380 (K, U). In morphology, this specimen is connected via a number of intermediates to more normal $N$. biserrata as occurring in South America, where specimens are mostly hairy, and indusia are inconspicuous in the ripe sori.

Nephrolepis platyotis probably represents an aberrant form (see under Cultivars and Monstrosities) with large acroscopic auricles.

4. Nephrolepis brownii (Desv.) Hovenkamp \& Miyam., comb. nov. - Fig. 1f; Map 2; Plate 1a

Nephrodium brownii Desv. (1827) 252. - Type: R. Brown 20 (BM, K), Australia.

Nephrodium regulare Desv. (1827) 252. - Type: Anon. s.n. (P), Timor.

Aspidium floccigerum Blume (1828) 147. - Nephrolepis floccigera (Blume) T. Moore (1857) 92;

Baker (1867) 302; Backer \& Posth. (1939) 93. - Type: Anon. s.n. (L? not found), Moluccas.

Aspidium schkuhrii Blume (1828) 147. - Type: Kuhl \& Van Hasselt s.n. (L), Java.

Nephrolepis acutangula C. Presl (1836) 79. - Type: Meyen s.n. (PRC), China.

Davallia multiflora Roxb. (1844) 515, pl. 31. - Nephrolepis multiflora (Roxb.) C. V. Morton (1958)

309; Proctor (1989) 265; Nauman (1992) 287. - Type: Roxburgh s.n. (BR), India.

Nephrolepis tomentosa Alderw. (1911) 11. - Type: Koorders $24101 b$ (BO, L), Java.

Nephrolepis pubescens Copel. (1952) 12; (1958) 187. - Type: BS 11539 (MICH), Philippines.

Nephrolepis hirsutula auct. non (G. Forst) C. Presl: Mickel \& A.R. Sm. (2004) 407.

Habit, rhizome morphology. Plants forming tufts of 5 or 6 fronds. Runners often forming stilts supporting the upright rhizome, $1.5-2.5 \mathrm{~mm}$ thick, branching angle divaricate. Scales on runners sparse, appressed or spreading. Tubers absent. Fronds $70-130$ by $10-12 \mathrm{~cm}$, stipe $14-37 \mathrm{~cm}$ long. Lamina base more or less strongly reduced, tapering over $25-35 \mathrm{~cm}$, basal pinnae $1.5-2 \mathrm{~cm}$ long, 2-5 cm distant, middle pinnae straight or slightly falcate. Sterile pinnae 6 by $1.4 \mathrm{~cm}$, base slightly to strongly unequal, basiscopic base rounded or cordate, acroscopic base truncate, strongly auricled (usually with a narrow auricle), margin in basal part entire or crenate, apex acute. Fertile pinnae $5.5-7$ by $0.9 \mathrm{~cm}$, with more distinctly serrate margin than the sterile pinnae. Indument. Basal scales peltate, appressed, 3.5 by $1.3 \mathrm{~mm}$, central part dark brown or blackish, shining, hyaline margin wide, distinct, marginal glands absent, margin in basal part ciliate, acumen ciliate. Rachis scales dense, spreading, hyaline or light brown, with a 
well-developed protracted entire or ciliate acumen (ciliate in the lower part). Scales on lamina usually persistent, often also persistent on upper surface. Hairs on lamina absent, on costa constantly present. Sori marginal or submarginal (rarely), 25-27 pairs on fully fertile pinnae, round. Indusium reniform, with narrow sinus, attached at sinus.

Distribution - Widespread in Tropical Asia. India, Sri Lanka, China (south only: Guangdong, Hainan, Hong Kong), Japan: Ryukyu Isl., Bonin Isl.; Taiwan, Indochina, Malesia: Java, Borneo, Celebes, Philippines, Lesser Sunda Islands, Moluccas?, New Guinea; New Caledonia, Australia: Queensland; New Zealand: Kermadec Isl; Fiji: Ovalau; Pitcairn; Rapa; Society Isl.; Cook Isl.: Rarotonga; Tonga. Introduced in Tropical America and the Hawaiian Islands.

Judging by the distribution of early collections, almost certainly native in Malesia, but dubiously elsewhere. It is introduced in America, where it is spreading as a weed and classified as an invasive species in Florida (http://www.fleppc.org/Plantlist/03list.htm). While Brown \& Brown (1931) suggest it is also introduced in Southeast Polynesia, the earliest collections in that area suggest that this must then have been done by the Polynesian settlers. Early collections in Polynesia were made by Banks on Maietea in 1769 (BM); by Banks \& Solander (BM) on Otaheite and by David Nelson in 1787 or earlier on Otaheite and in the Friendly Islands.

In contrast, it appears to be completely absent from Africa, and is uncommon in most parts of the Indian subcontinent.

Habitat \& Ecology - Common at low to middle elevations (sea level to $1700 \mathrm{~m}$ ), usually terrestrial, also epiphytic, both in forests and open vegetation (roadsides, riverbanks, open thickets), often weedy.

Notes - This species has often been confused with $N$. hirsutula. It was distinguished from this by Jarrett in Morton (1974) as $N$. multiflora, on the basis of the presence of hairs on the upper side of the pinna-midribs. Other characters to distinguish these two species are discussed under $N$. hirsutula.

Similar scales and costal indument is found in N. acuminata, which is, however, easily distinguished by the rachis indument including at least some scales with a dark acicular apex.

On Hawaii aberrant forms with spreading basal scales occur, some apparently with good spores (Fosberg 38625, K), some apparently sterile (Fosberg 55434, L).

\section{Nephrolepis cordifolia (L.) C. Presl - Fig. 1j; Map 3; Plate 2d}

Nephrolepis cordifolia (L.) C. Presl (1836) 79; Baker (1867) 300; Backer \& Posth. (1939) 91; Copel. (1958) 186; Holttum (1968) 379; Tagawa \& K. Iwats. (1985) 172; Proctor (1989) 262; Nauman (1992) 287; Verdc. (1996) 539; (2001) 7; Mickel \& A.R. Sm. (2004) 405. - Polypodium cordifolium L. (1753) 1089. - Aspidium cordifolium (L.) Sw. (1801) 32; (1806) 45. — Lectotype (Verdcourt, 1996): Ekman H11627 (K), Hispaniola.

Polypodium auriculatum L. (1759) 1326 (nom. rej.). - Nephrolepis auriculata (L.) Trimen (1888)

152; Verdc. (1996) 540. - Lectotype (Verdcourt, 1996): Herb. Hermann s.n. (BM), Ceylon. Aspidium tuberosum Bory (1810) 234. - Nephrodium tuberosum (Bory) Desv. (1827) 252. -

Nephrolepis tuberosa (Bory) C. Presl (1836) 79. - Type: Anon. s.n. (B-Willd., L, P), Réunion. Nephrodium edule D. Don (1825) 5. - Type: Hamilton s.n. (n.v.), India. Aspidium imbricatum Spreng. (1827) 97. - Nephrolepis imbricata (Spreng.) C. Presl (1836) 79.

- Nephrodium imbricatum (Spreng.) Bojer (1837) 392. - Type: Sieber 41 (K), Mauritius. Nephrolepis rhizodes Kunze (1848a) 236. - Type: Zollinger 2526 (L). 
Nephrolepis intramarginalis Kunze (1850) 268. - Type: Anon. s.n. cult. in hort. Lips. (L), cultivated.

Nephrolepis flexuosa Colenso (1888) 231. - Type: Colenso s.n. (K).

Habit, rhizome morphology. Plants forming tufts of 3-7 fronds. Runners $0.5-1.5 \mathrm{~mm}$ thick, branching angle divaricate. Scales on runners very sparse to dense, spreading or squarrose (occasionally). Tubers present or absent. Fronds to $40-120$ by $2-6 \mathrm{~cm}$, stipe $4-15 \mathrm{~cm}$ long. Lamina base strongly reduced, tapering over $10-25 \mathrm{~cm}$, basal pinnae 4-10 cm long, 0.7-1.7 cm distant, middle pinnae slightly to distinctly falcate. Sterile pinnae $1-3.3$ by $3-9 \mathrm{~mm}$, herbaceous, thick, base slightly to strongly unequal, basiscopic base rounded or cordate, acroscopic base cordate, distinctly to strongly auricled, margin in basal part dentate, towards apex deeply dentate, apex rounded or obtuse. Fertile pinnae $1.6-3.2$ by $0.4-0.8 \mathrm{~cm}$, otherwise similar to sterile ones. Indument. Basal scales pseudopeltate, spreading, 8 by $1 \mathrm{~mm}$, central part light brown, dull, margin in basal part irregularly lacerate, not hyaline, towards apex denticulate, without marginal glands, apex narrow, not long uniseriate. Rachis scales sparse or dense, spreading, light brown, with lacerate base and a well-developed protracted entire acumen. Scales on lamina absent. Hairs on lamina absent or sometimes present, costa absent. Sori medial, 6-15 pairs on fully fertile pinnae, elongated, not impressed. Indusium lunulate or broad, attached at broad base.

Distribution - Africa: Madagascar, Mauritius, Seychelles, Sao Tomé, Cameroon; Asia: India, Sri Lanka, Burma?, China, Japan, Taiwan, Indochina: Tonkin; throughout Malesia; Pacific: New Caledonia, New Hebrides; Australia: Queensland down to Northern end of NSW, Lord Howe Isl.; New Zealand (North Island, Norfolk, Kermadec); Pacific Islands. Hawaii (cultivated?), Samoa. Often cultivated and possibly as garden escape in some localities.

Habitat \& Ecology - In tropical regions mostly at middle elevations (800-2000 $\mathrm{m}$ ), occasionally higher (collections from lower elevations are probably from cultivated

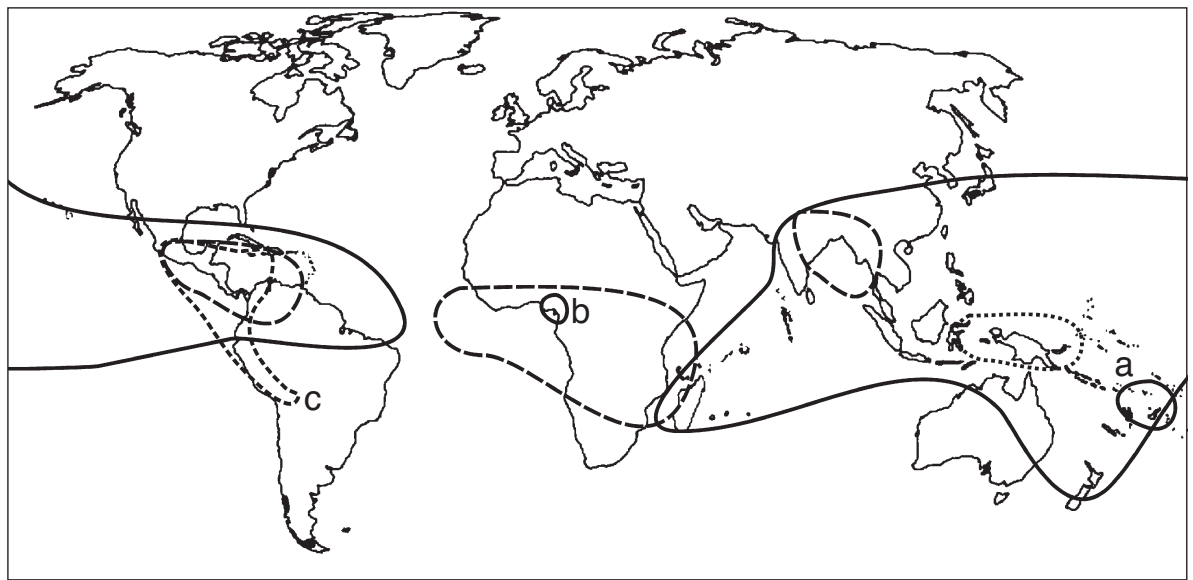

Map 3. Distribution of Nephrolepis cordifolia (L.) C. Presl (continuous line; a = var. pseudolauterbachii; $\mathrm{b}=$ var. pumicicola), N. lauterbachii $\mathrm{H}$. Christ (dotted line), N. pectinata (Willd.) Schott (broken line c) and N. undulata (Afzel.) J.Sm. (broken line). 
plants), often in submontane or ridge forest, mostly terrestrial (often on rotting logs), rarely epiphytic; rarely in fully open situations. In subtropical areas often growing at lower elevation.

Notes - Runners in this species can be with or without scaly tubers, the presence of which (at least when judged from the presence in herbarium specimens) seems to be erratic, not correlated to other characters. They are produced mainly on underground runners - the aerial parts appear to form tubers more sporadically. In cultivation, the tubers can be observed to shrivel and disappear when plants are kept dry - in nature the presence may be similarly dependent on periods of moist conditions. For these reasons, it is impossible to use herbarium collections to assess the frequency with which tubers are formed.

In the Neotropics, $N$. cordifolia is at many sites apparently escaped from cultivation. It may be native perhaps only in the central portion of the range (Cuba to Venezuela).

\section{KEY TO THE VARIETIES}

1a. Rhizome short, fronds erect to arching, pinnae in a plane with the rachis . . . 2

b. Rhizome elongate, forming a distinct erect trunk, fronds stiffly erect, pinnae perpendicular to rachis $\ldots \ldots \ldots \ldots \ldots \ldots \ldots \ldots \ldots \ldots \ldots \ldots$ c. var. pumicicola

2a. Pinnae with basiscopic base rounded to cordate, margins straight

a. var. cordifolia

b. Pinnae with basiscopic base narrowed, margins sinuose.

b. var. pseudolauterbachii

\section{a. var. cordifolia}

Rhizome creeping or upright, not forming a trunk, fronds erect to arching, to $70 \mathrm{~cm}$ long, pinnae usually more or less in the plane of the rachis, pinna-base more or less equal on both sides of the attachment, pinna margins straight.

Notes - In New Zealand N. cordifolia is reported as a garden escape or near warm streams by Brownsey \& Smith-Dodsworth (1989). They distinguish the introduced plants (as N. cordifolia) from a 'native species', but their native species is exactly this variety, and the introduced forms therefore probably refer to a restricted number of vegetatively propagated cultivars.

In Africa, specimens which can be attributed to this variety occur only on the islands in the Indian Ocean (Madagascar, Réunion, Seychelles), while specimens from the continent with very few exceptions are referable to $N$. undulata. The few scattered specimens of $N$. cordifolia in the East of Africa may well be garden escapes, as suggested by Verdcourt (2001).

b. var. pseudolauterbachii Hovenkamp \& Miyam., var. nov. - Map 3a

Ab var. cordifolia differt frondis brevioris, $20-45 \mathrm{~cm}$ longis, $0.8-3 \mathrm{~cm}$ latis, pinnis fertilis sinuosis, basi inaequalis, paucisoris; ab $N$. lauterbachii differt paleis rachidis pallidis, stipidis simile. - Typus: T. Nakamura et al. 668 (holo TUAT; iso B, BISH, BM, BRI, F, K, MICH, NSW, NY, P, PNH, TAI), Fiji, Viti Levu, Namosi, 16 March 1986. 
Differs from the type variety in smaller fronds, to $20-45$ by $0.8-3 \mathrm{~cm}$, fertile pinnae sinuose, with distinctly unequal base, bearing few sori; differs from $N$. lauterbachii in scales on the rachis similar to those on the stipe.

Distribution - Pacific Islands: Vanuatu, Fiji, Samoa.

Habitat \& Ecology - Between 600-1700 m, generally in similar situations as the type variety.

Note - A small form strongly resembling N. lauterbachii, but without dark rachis scales characteristic for that species, and also with less distinctly asymmetric bases of the sterile pinnae, and not showing the regularly proliferous stolons. From N. cordifolia var. cordifolia it differs also in the absence of tubers.

c. var. pumicicola (F. Ballard) Hovenkamp \& Miyam., comb. nov. - Map 3b Nephrolepis pumicicola F. Ballard (1955) 467. - Type: Keay 28655 (K).

Differs from the type variety: Rhizome thin, upright, up to $10 \mathrm{~cm}$ high, fronds stiffly erect, narrow, to 120 by $3-3.5 \mathrm{~cm}$; pinnae perpendicular to rachis.

Distribution - Africa: Sao Tomé, Cameroon.

Habitat \& Ecology - At low elevations to 1500 m, terrestrial, often in crevices of young volcanic rocks.

Note - This variety is restricted to the Gulf of Guinea. It is relatively easy to recognize when compared with the in Africa widespread species $N$. undulata by its perennial habit, the stem-forming rhizome (but this may not be evident in all specimens) bearing rigidly erect fronds with numerous, small pinnae at right angles to the plane of the rachis. None of these characters provide a clear basis for a distinction as a separate species, as all occur to varying degrees in $N$. cordifolia from other regions. Moreover, some specimens also collected on lava show a more relaxed habit, with less distinctly horizontal pinnae and a less stiffly erect habit, and thus are closer to typical N. cordifolia (e.g., Benl \& Benl FP 54, Fernando Po; Mildbraed 10678). For these reasons, we include this as a variety in $N$. cordifolia. However, a number of collections from the Virunga Mountains (Congo) include plants forming small tufts (Burtt 3280, $\mathrm{K}$, "frequent inside crater") as well as plants with the typical rhizome of N. undulata (Burtt 3117, K, "lava plains"). Clearly, more detailed investigations are necessary to decide whether $N$. pumicicola is here rightly included in $N$. cordifolia, or whether it should be included, as a perennial variety, in $N$. undulata.

\section{Nephrolepis davalliae Alderw. - Fig. 1i; Map 4}

Nephrolepis davalliae Alderw. (1908) 2. - Type: Versteeg 1675 (BO, L), New Guinea. Nephrolepis schlechteri Brause (1913) 24. - Type: Schlechter 19639 (BM, K, L, P), New Guinea.

Habit, rhizome morphology. Plants forming tufts of 3-8 fronds. Runners 1-1.5 mm thick (polished), unbranched. Scales on runners sparse, spreading or squarrose. Tubers absent. Fronds 50-115 cm long (or more), 4-8 cm wide, stipe 8-15 cm long. Lamina base reduced, tapering over $20-25 \mathrm{~cm}$, basal pinnae $1.2-2.7 \mathrm{~cm}$ long, $1.2-1.5 \mathrm{~cm}$ distant, middle pinnae straight or slightly falcate. Sterile pinnae $2-4.3$ by $0.4-0.7 \mathrm{~cm}$, leathery, base equal or slightly unequal, basiscopic base truncate or rounded, acroscopic 


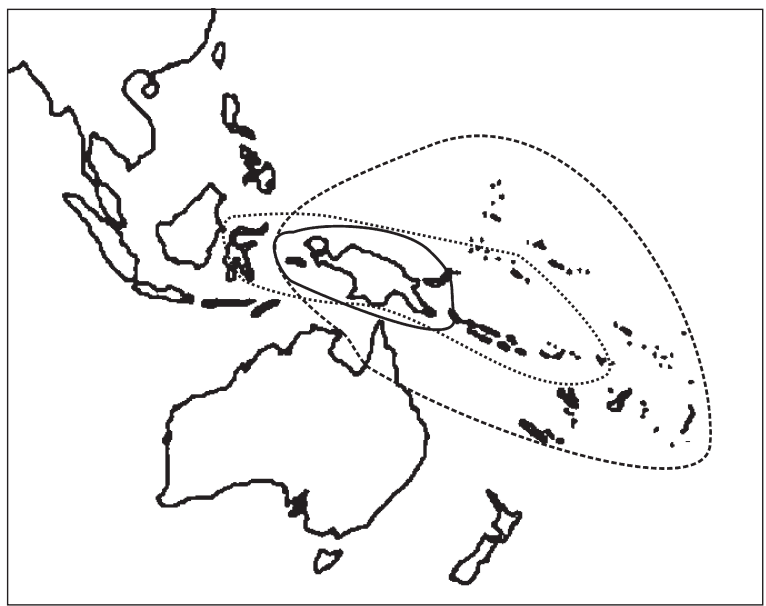

Map 4. Distribution of Nephrolepis davalliae Alderw. (continuous line), N. dicksonioides H. Christ (dotted line) and N. obliterata (R.Br.) J.Sm. (broken line).

base cuneate or truncate, not to slightly auricled, margin in basal part crenate, towards apex serrate, apex acute. Fertile pinnae $1.8-4.7$ by $0.3-0.6 \mathrm{~cm}$, with a more longly drawn out apex than the sterile pinnae. Indument. Basal scales pseudopeltate, appressed or spreading, 3.5 by $0.3-0.7 \mathrm{~mm}$, central part rufous, dull, margin not hyaline, in basal part irregularly lacerate (protrusions most unicellular), in acumen entire or dentate (remotely, with two-celled teeth), marginal glands present around the scale. Rachis scales with a well-developed protracted acumen, appressed or spreading (sometimes recurved), dark, acumen entire or dentate. Scales on lamina usually persistent (more so on the upper surface), small, more or less stellate/lacerate. Sori marginal on teeth, 7-14 pairs on fully fertile pinnae, round or elongated, protruding on adaxial surface. Indusium broad, attached at base and sides.

Distribution - Moluccas, New Guinea, New Britain.

Habitat \& Ecology - Montane or ridge forest (500-2150 m, rarely lower), epiphytic or terrestrial, often forming large stands covering open places.

Note - Easily characterized by the leathery texture of the lamina, with indistinct veins, and the marginal sori, each opening to the anterior side of a separate tooth, covered with a cup-shaped indusium.

\section{Nephrolepis davallioides (Sw.) Kunze - Fig. 1c; Map 5; Plate 2b}

Nephrolepis davallioides (Sw.) Kunze (1846) 460; Baker (1867) 302; Holttum (1954) 634; Tagawa \& K. Iwats. (1985) 172. - Ophioglossum acuminatum Houtt. (1783) 49. - Aspidium davallioides Sw. (1801) 33; Blume (1828) 148. - Nephrodium davallioides (Sw.) Desv. (1827) 254. - Nephrolepis acuminata (Houtt.) Kuhn (1869) 286; Backer \& Posth. (1939) 93; Holttum (1968) 378 (nom. illeg. non C. Presl 1836). - Type: Plate in Houttuyn. Nephrodium deparioides Bory (1833) 59. - Type: Belanger s.n. (P), Java. Nephrolepis pendula de Vriese (1846) 8 (nom. illeg. non J. Sm. 1842a). - Type: Reinwardt 1564 (L), Celebes.

Nephrolepis serrata Alderw. (1918) 34. - Type: Kornassi 626 (BO), Ceram. 
Habit, rhizome morphology. Plants forming tufts of 4 or 5 fronds. Runners 1-2 mm thick, branching angle narrow. Scales on runners very sparse to dense, appressed. Tubers absent. Fronds $110-210 \mathrm{~cm}$ long (or more), 26-38 cm wide, stipe 23-45 cm long. Lamina base truncate, tapering over $25-30 \mathrm{~cm}$, basal pinnae 4-12 cm long, 3.5-12 $\mathrm{cm}$ distant, middle pinnae slightly to distinctly falcate. Sterile pinnae $14-18$ by $1.7-2.4$ $\mathrm{cm}$, base slightly unequal, basiscopic base cuneate, truncate or rounded, acroscopic base emarginate or slightly cuneate, not auricled, margin in basal part crenate to serrate, towards apex more distinctly serrate, apex acuminate or caudate with cauda to 3 $\mathrm{cm}$ long. Fertile pinnae $14-28$ by $1.1-1.4 \mathrm{~cm}$, base often more narrowly cuneate and margin more deeply incised (to $2-3.5 \mathrm{~mm}$ ) than the sterile pinnae. Indument. Basal scales peltate, appressed, 3 by $1 \mathrm{~mm}$, central part dark brown, shining, margin in basal part hyaline, fimbriate, in acumen fimbriate, near apex entire, marginal glands present around the base. Rachis scales dense, with a well-developed protracted acumen, spreading or squarrose, hyaline, acumen ciliate (acumen of larger scales composed of a long, sclerified subular protrusion). Scales on lamina usually persistent, sparse, present on lower surface only. Hairs on lamina absent, costa absent. Sori marginal (on teeth), 28-50 pairs on fully fertile pinnae, round, not impressed. Indusium reniform, with narrow sinus, attached at sinus.

Distribution - Restricted to Malesia: Peninsular Thailand, Peninsular Malaysia, Sumatra, Celebes, Borneo, Java, New Guinea.

Habitat \& Ecology - Common in forests at middle elevations (800-1600 m), rarely lower $(200 \mathrm{~m}$ ) or higher (up to $2100 \mathrm{~m}$ ). Usually in forest, terrestrial, often on roadside or stream banks; more often epiphytic, often on trunks.

Note - Typical specimens have deeply dissected fertile pinnae, with sori nearly marginal, on separate teeth, and the lamina between the sori cut to c. 1/2. However, many specimens (especially from the eastern part of the distribution area) have less

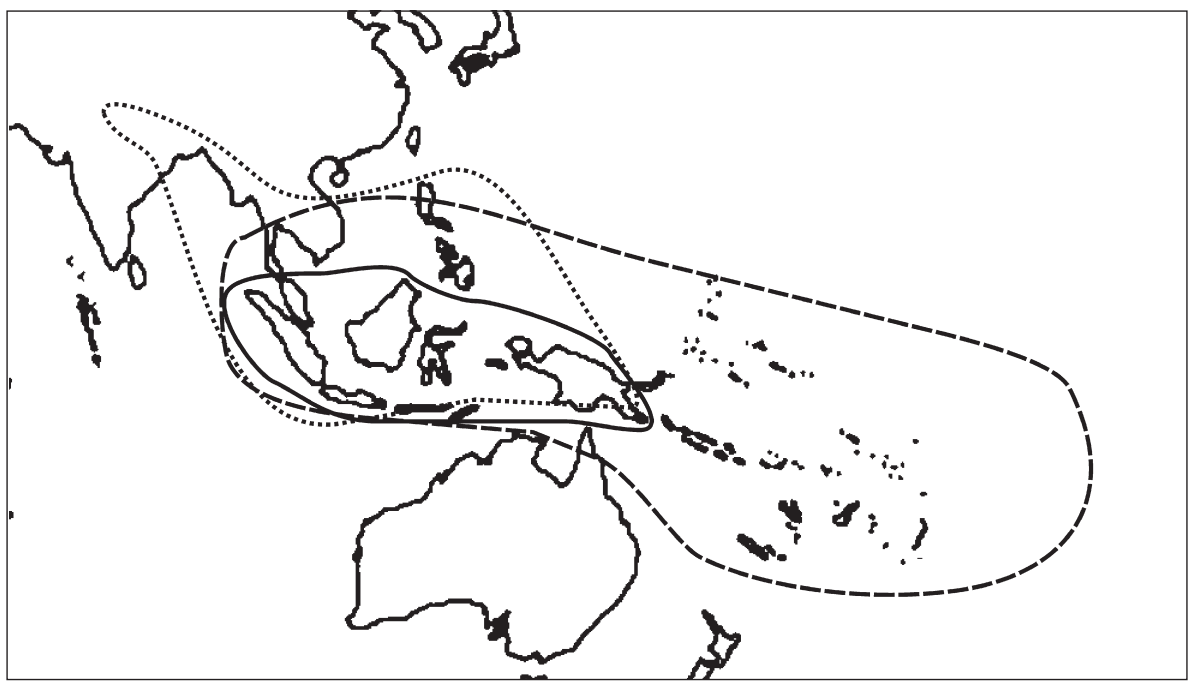

Map 5. Distribution of Nephrolepis davallioides (Sw.) Kunze (continuous line), N. hirsutula (G. Forst.) C. Presl (broken line) and N. radicans (Burm.) Kuhn (dotted line). 
deeply divided pinnae, and such specimens can easily be confused with other species. They can best be distinguished by the rachis indument, which consists of scales with a narrow, dark acumen, sometimes needle-like, often directed sideways towards the upper surface. Hairs are sometimes present on the upper surface of the costae, usually near the base only, situated on short, narrow lines of paler tissue.

\section{Nephrolepis dicksonioides H. Christ - Fig. 1b; Map 4}

Nephrolepis dicksonioides H. Christ (1895) 241; Holttum (1968) 376. - Dicksonia nephrolepioides H. Christ (1895) 241. - Type: Sarasin 1030 (P n.v.), Celebes. [The type (Sarasin 1030) could not be located; however, its origin in Celebes puts it beyond doubt that it is this species and not N. abrupta with which it has been confused.]

Nephrolepis rosenstockii Brause (1913) 25. - Type: Schlechter 16494 (K, L, P), New Guinea.

Habit, rhizome morphology. Plants forming tufts of 2 or 3 fronds. Runners $1.5-2 \mathrm{~mm}$ thick, branching angle divaricate. Scales on runners dense, spreading. Tubers absent. Fronds $200 \mathrm{~cm}$ long (or more), 16-18 cm wide, stipe 33-35 cm long. Lamina base strongly reduced, tapering over $30 \mathrm{~cm}$, basal pinnae $1.2-2.5 \mathrm{~cm}$ long, $4-6 \mathrm{~cm}$ distant, middle pinnae slightly to distinctly falcate. Sterile pinnae $9.5-11$ by $1.6-2 \mathrm{~cm}$, leathery, base strongly unequal, basiscopic base rounded or cordate, acroscopic base cuneate or truncate, not auricled, margin in basal part entire, towards apex crenate or serrate, apex acuminate or to $1.5-2.5 \mathrm{~cm}$ caudate. Fertile pinnae $10-15$ by $0.6-1.2 \mathrm{~cm}$, different from sterile pinnae in the margin deeply incised between the sori, especially towards pinna-apex, and the apex more gradually narrowed to a $2.5-4 \mathrm{~cm}$ long cauda. Indument. Basal scales pseudopeltate, spreading, 5 by $2-2.5 \mathrm{~mm}$, central part rufous, shining, marginal glands absent, margin not hyaline, in basal part ciliate or fimbriate, in acumen ciliate or fimbriate. Rachis scales dense, with a well-developed protracted acumen, appressed (inconspicuous), hyaline or light brown, acumen ciliate. Scales on lamina absent. Hairs on lamina and costa absent. Sori marginal (or nearly marginal), often on dilated teeth, especially towards the pinna-apex, 20-32 pairs on fully fertile pinnae, elongated (sometimes confluent near the base of the pinna), not impressed. Indusium broad, attached at broad base.

Distribution - Eastern part of Malesia: Celebes, Moluccas, New Guinea, Solomon Islands.

Habitat \& Ecology - Terrestrial, on rocks, or epiphytic. Disturbed places in lower montane forest, in ridge forest or disturbed secondary forest, 400-1900 m.

Note - Nephrolepis dicksonioides has been confused with N. abrupta and N. acuminata. It has fertile pinnae similarly incised as typical specimens of N. acuminata, and marginal sori similar to those of $N$. abrupta, but differs from both in the indusium having a broad base, innervated by 2 or 3 veins. The apex of the sorus-bearing tooth is often dilated. From N. abrupta it can also be distinguished by the shape of the pinnae: the fertile ones are more constantly deeply divided, the sterile ones more distinctly acuminate, narrowing to a distinct cauda from c. halfway.

\section{Nephrolepis exaltata (L.) Schott - Map 6}

Nephrolepis exaltata (L.) Schott (1834) Pl. 3; Brack. (1854) 211; Baker (1867) 301; Backer \& Posth. (1939) 91; Copel. (1958) 188; Proctor (1989) 262; Nauman (1992) 287; Verdc. (2001) 4; Mickel \& A.R. Sm. (2004) 406. - Polypodium exaltatum L. (1759) 1326. - Aspidium exaltatum (L.) 
Sw. (1801) 32; R. Br. (1810) 148; Blume (1828) 146. - Nephrodium exaltatum (L.) R. Br. (1810) 148; Desv. (1827) 252. - Hypopeltis exaltata (L.) Bory (1833) 66. - Type: Sloane s.n. (1: 52, BM n.v.), Jamaica.

Nephrolepis cultrifolia C. Presl (1836) 79. - Type: Meyen 1835 (PRC), Ouwahu.

Nephrolepis neglecta Kunze (1839a) 149. - Type: Schiede 766 (lost, photo in BM), Mexico.

Nephrolepis dentata Goldm. (1843) 463. - Type: Meyen s.n. (n.v.), Hawaii.

Nephrolepis exaltata (L.) Schott subsp. hawaiiensis W.H. Wagner et al. (1999) 182. - Type: Wagner et al. 9621 (MICH n.v.), Hawaii.

Habit, rhizome morphology. Plants epiphytic or terrestrial (less often epilithic), forming tufts of 4 or 5 fronds. Runners $0.2-1.5 \mathrm{~mm}$ thick. Scales on runners sparse, spreading. Tubers absent. Fronds $40-150$ by $5-12 \mathrm{~cm}$, stipe $2-39 \mathrm{~cm}$ long. Lamina base strongly reduced, tapering over $20-25 \mathrm{~cm}$, basal pinnae $0.6-3 \mathrm{~cm}$ long, $2-2.5 \mathrm{~cm}$ distant, middle pinnae slightly to distinctly falcate. Sterile pinnae $2.3-7.4$ by $0.6-1.8$ $\mathrm{cm}$, herbaceous, thick, base slightly to strongly unequal, basiscopic base truncate, rounded to cordate, acroscopic base truncate, distinctly auricled, margin in basal part entire or crenate, towards apex more deeply serrate or dentate, apex obtuse or acute. Fertile pinnae $2.3-5.9$ by $0.6-1.5 \mathrm{~cm}$, otherwise similar to sterile ones. Indument. Basal scales peltate, spreading, $2-9$ by $0.4-1.3 \mathrm{~mm}$, central part light brown or dark brown, dull, margin not hyaline, in basal part entire, denticulate or dentate, in acumen entire or denticulate, marginal glands absent. Rachis scales with a well-developed protracted acumen. Scales on lamina sometimes present. Hairs on lamina absent, on costae absent. Sori submarginal or medial, 9-16 pairs on fully fertile pinnae, round or elongated, not impressed. Indusium reniform, with open sinus, attached at sinus or at broad base.

Distribution - Florida, the Bahamas, Turks \& Caicos, Cuba, Hispaniola, Puerto Rico, Jamaica, Mexico (Veracruz only), Bermuda, Panama, French Guyana (one specimen seen), Hawaii. The occurrence on Henderson and Rapa reported by Brown \& Brown (1931) is so far not confirmed.

Habitat \& Ecology - Occurs in a variety of habitats, at low to middle elevations (sea level to $1170 \mathrm{~m}$ ).

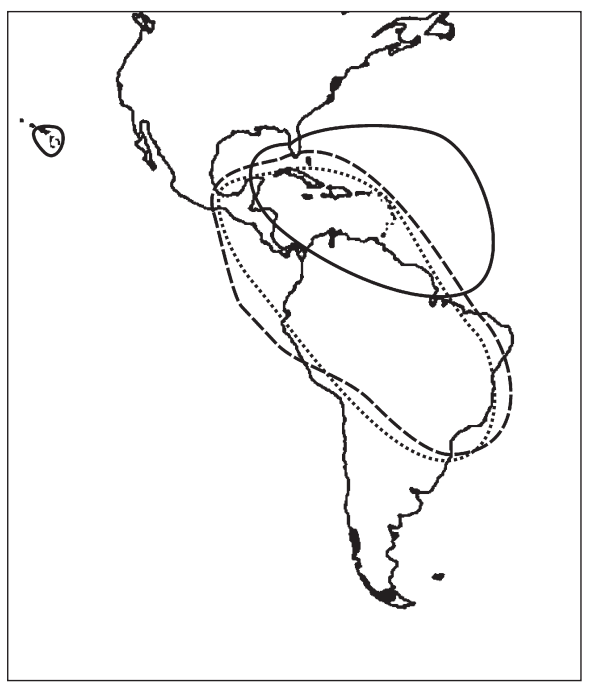

Map 6. Distribution of Nephrolepis exaltata (L.) Schott (continuous line), N. pendula (Raddi) J.Sm. (broken line) and N. rivularis (Vahl) Mett. ex Krug (dotted line). 
Notes - Nephrolepis exaltata is supposed to be the source for $N$. 'bostoniensis' and all cultivars derived from it, which are widely cultivated. The name has been widely, and mistakenly, applied to specimens from all over the world.

Introductions: contrary to what might be expected, $N$. exaltata does not seem to naturalize often outside its native range. Most of the naturalized occurrences concern islands in the Atlantic, and may be difficult to distinguish from native occurrences. On the Canary Islands, it is considered as an introduction by Hohenester \& Wells (1993), but on Bermuda as native by Britton (1918). One collection was seen from St Helena (Packer HL 10, Jamestown), where it is possibly introduced. Some specimens are apparently collected in the wild in Africa and are regarded as naturalized escapes by Verdcourt (2001). Specimens were collected on the Hawaiian Islands as early as 1788 (David Nelson s.n., BM) 1825 (Macrae s.n., BM) and 1837 on Oahu (Barclay 1227, BM), and N. exaltata should be regarded as native there. Wagner et al. (1999) distinguished the Hawaiian population as subsp. hawaiiensis on basis of a comparison with the Caribbean population, but most of their distinguishing characteristics fall within the range of $N$. exaltata if the Florida specimens are taken into account.

10. Nephrolepis falcata (Cav.) C. Chr. - Map 7; Plate $2 \mathrm{~h}$

Nephrolepis falcata (Cav.) C. Chr. (1936) 15, pl. 1, f. 5-9; Copel. (1958) 188. - Tectaria falcata

Cav. (1801) 250. - Type: Née s.n. (BM, fragm., MA), Philippines.

Nephrolepis barbata Copel. (1905) 178. - Type: Copeland 1286 (MICH), Philippines.

Habit, rhizome morphology. Runners 1-1.5 mm thick, branching angle narrow. Scales on runners very sparse or sparse, appressed. Tubers absent. Fronds $65-200 \mathrm{~cm}$ long (or more), 7-10 cm wide, stipe 10-34 cm long. Lamina base strongly reduced, tapering over $20-35 \mathrm{~cm}$, basal pinnae $0.7-1 \mathrm{~cm}$ long, $1.5-3.5 \mathrm{~cm}$ distant, middle pinnae distinctly to strongly falcate. Sterile pinnae $4-8$ by $1-1.4 \mathrm{~cm}$, herbaceous, thick, base

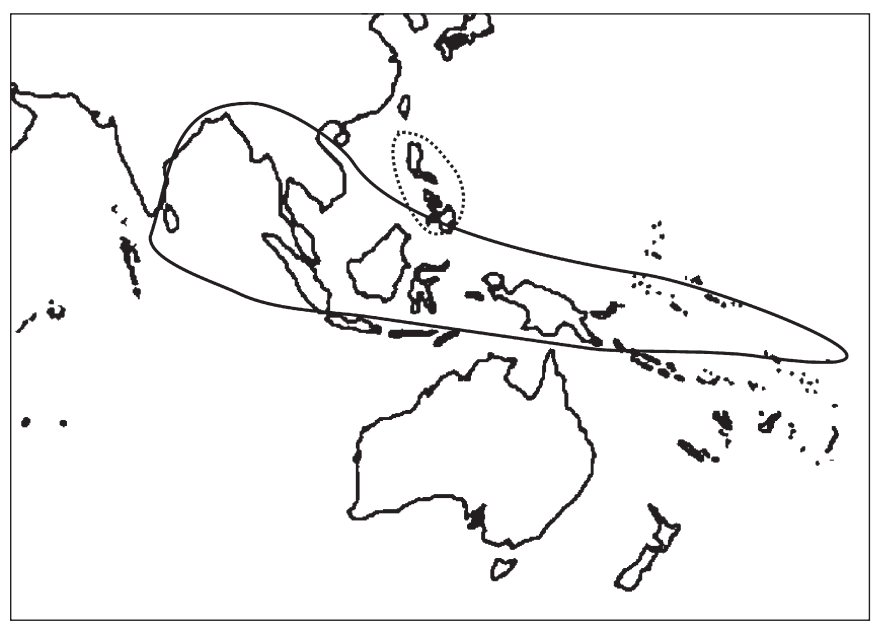

Map 7. Distribution of Nephrolepis falcata (Cav.) C. Chr. (continuous line) and N. falciformis J.Sm. (dotted line). 
strongly unequal, basiscopic base rounded, acroscopic base truncate, slightly to distinctly auricled, margin in basal part crenate, dentate or serrate, apex acute to (indistinctly) $1 \mathrm{~cm}$ caudate. Fertile pinnae $4.8-8$ by $0.7-1.2 \mathrm{~cm}$, otherwise similar to sterile ones. Indument. Basal scales peltate, appressed, 2 by $0.5-1 \mathrm{~mm}$, central part blackish, shining, hyaline margin narrow, marginal glands absent, margin in basal part irregularly lacerate or ciliate, acumen ciliate. Rachis scales dense, with a well-developed protracted acumen, squarrose to recurved, dark, with entire acumen. Scales on lamina usually persistent, with a long, narrow, entire, acicular acumen. Hairs on lamina and costa absent. Sori submarginal, 19-29 pairs on fully fertile pinnae, round, not impressed. Indusium reniform, with narrow sinus, attached at sinus.

Distribution - Philippines: Luzon, Samar, Negoro, Mindanao.

Habitat \& Ecology - Few data. Reported from lowlands to high elevations (300$2500 \mathrm{~m}$ ), in forest and in severely disturbed areas, epiphytic or terrestrial.

Note - Similar in pinna shape and position of the sori to $N$. falciformis, but differs in the very dark, dense, squarrose rachis scales; the denser and more persistent lamina scales, and the absence of hairs on the costae. Juvenile specimens of $N$. davallioides may have a similar rachis indument and may then be impossible to distinguish from sterile fronds of $N$. falcata.

\section{Nephrolepis falciformis J. Sm. - Map 7; Plate 2g}

Nephrolepis falciformis J. Sm. (1866) 287. - Type: Anon. s.n. (BM), Borneo. Nephrolepis thomsonii Alderw. (1917) 2. - Type: Thomson 690 (BO, L), New Guinea. Nephrolepis cordifolia (L.) C. Presl var. calcarea H. Christ (1909) 158. - Type: Versteeg 1614 (1603?) (BO, K), New Guinea.

Nephrolepis falcata auct. non (Cav.) C. Chr.: Holttum (1968) 381; Tagawa \& K. Iwats. (1985) 176.

Habit, rhizome morphology. Plants forming tufts of 2-4 fronds. Runners 1-2 mm thick, frequently branched, branching divaricate. Scales on runners sparse, appressed. Tubers absent. Fronds $150-200 \mathrm{~cm}$ long (or more), 9-14 cm wide, stipe $16-45 \mathrm{~cm}$ long. Lamina base reduced, tapering over $20-50 \mathrm{~cm}$, basal pinnae $1.5-2.5 \mathrm{~cm}$ long, $4.5-5 \mathrm{~cm}$ distant, middle pinnae usually strongly falcate (basal and apical pinnae usually far less so). Sterile pinnae $5-6$ by $1.1-1.8 \mathrm{~cm}$, herbaceous, thick (often conspicuously pale green when dry), base strongly unequal, basiscopic base rounded, acroscopic base truncate, slightly to distinctly auricled, margin in basal part entire or crenate, apex acute or acuminate. Fertile pinnae $5.3-8$ by $1-1.3 \mathrm{~cm}$, with a more distinctly dentate margin than from sterile pinnae. Indument. Basal scales peltate, appressed, 3.5 by 1 $\mathrm{mm}$, central part dark brown, dull, hyaline margin wide, distinct, ciliate throughout, marginal glands absent. Rachis scales sparse, without a distinctly protracted acumen, appressed, dark, conspicuous especially when dry. Scales on lamina sometimes present, very small, inconspicuous. Hairs on lamina absent, on costa sometimes present, few (usually forming a small group of scattered hairs near the base). Sori submarginal, 21 or 22 pairs on fully fertile pinnae, round, slightly impressed. Indusium reniform, with narrow sinus, attached at sinus.

Distribution - Sri Lanka, Indochina, Malesia: Peninsular Thailand, Sumatra, Malay Peninsula, Borneo, Celebes, Moluccas, New Guinea.

Habitat \& Ecology - At low to middle elevation (sea level to $800 \mathrm{~m}$, rarely higher), in forests, often in shade, also in open places, terrestrial or epiphytic. 
Notes - A fairly distinct species, most easily recognizable by the strongly falcate median pinnae and the strikingly light colour (fresh plants are bright green, dry specimens often, but not always, a pale yellowish brown). The degree to which the pinnae are falcate strongly varies within a single frond, with the median fertile pinnae often very pronouncedly falcate, with the apex frequently curved back somewhat towards the midrib, but the more basal and apical pinnae usually only slightly or not at all falcate. The sori are mostly nearly marginal, some hairs are usually present on the upper surface of the costae especially near the points of attachment, often forming a rather characteristic sparse tuft. The scales on rachis are small and sparse, but rather conspicuous due to the dark colour.

A distinct form occurs on New Guinea, which differs from the typical form in a number of aspects: fronds long, slender, often stated to be pendent, often many in a tuft, strongly narrowed at base to strongly reduced (semicircular) basal pinnae, middle pinna relatively small and not strongly falcate; rachis and fronds nearly glabrous, scales where present small. Typical plants of this form are at first sight similar to N. cordifolia, and have been distinguished as $N$. thomsonii and $N$. cordifolia var. calcarea. However, as all the characters that distinguish this form from typical $N$. falciformis show a very gradual transition between the two extreme states, we prefer to deal with it informally under this species.

\section{Nephrolepis hirsutula (G. Forst.) C. Presl - Fig. 1h; Map 5; Plate $2 \mathrm{f}$}

Nephrolepis hirsutula (G. Forst.) C. Presl (1836) 79; Brack. (1854) 211; Backer \& Posth. (1939) 92; Copel. (1958) 188; Holttum (1968) 382; Tagawa \& K. Iwats. (1985) 177. - Polypodium hirsutulum G. Forst. (1786) 81, Nicolson \& Fosberg (2003) 136. - Aspidium hirsutulum (G. Forst.) Sw. (1801) 32; (1806) 45, 241; Blume (1828) 146. - Polystichum hirsutulum (G. Forst.) Bernh. (1803) 16. - Lepidonevron hirsutulum (G. Forst.) Fée (1852) 301. - Nephrodium hirsutulum (G. Forst.) Desv. (1827) 253; C. Presl (1830) 32. - Type: Forster 278 (BM), without locality.

Nephrolepis duffii T. Moore (1878b) 622, f. 113; Backer \& Posth. (1939) 89. - Type: Anon. s.n. (K), in cult. Hort. Veitch.

Aspidium pilosum Langsd. \& Fisch. (1810) 14, t. 16. - Nephrolepis pilosa (Langsd. \& Fisch.) C. Presl (1836) 79. - Type: Langsdorff s.n. (BM).

Nephrodium multifidum A. Rich. (1834) xxxix. - Nephrolepis multifida (A. Rich.) Mett. (1856) 100. - Type: Lesson (Astrolabe) s.n. (P).

Habit, rhizome morphology. Plants forming tufts of 4-8 fronds (or more). Runners often forming stilts supporting the erect rhizome, 1-2 mm thick, branching angle narrow. Scales on runners sparse or dense, appressed or spreading. Tubers absent. Fronds $90-210$ by $15-20 \mathrm{~cm}$, stipe $32-80 \mathrm{~cm}$ long. Lamina base reduced, tapering over $15-30 \mathrm{~cm}$ (or more), basal pinnae $3.5-8 \mathrm{~cm}$ long, 2-5 cm distant, middle pinnae straight (sometimes recurved). Sterile pinnae $8-10$ by $1.2-1.6 \mathrm{~cm}$, herbaceous, thick, base strongly unequal, basiscopic base truncate or rounded, acroscopic base truncate, strongly auricled (with narrow auricle), margin in basal part entire, towards apex crenate, apex acute. Fertile pinnae $7.5-11$ by $0.9-1.1 \mathrm{~cm}$, more strongly crenate than the sterile pinnae. Indument. Basal scales peltate, appressed, $1.5-23.5$ by $1 \mathrm{~mm}$, central part dark brown or blackish, shining, hyaline margin wide, ciliate, marginal glands, absent apex obtuse. Rachis scales very dense, with a well-developed protracted acumen, spreading or squarrose, rufous, acumen strongly dentate. Scales on lamina usually 
persistent. Hairs absent from lamina and costae. Sori submarginal to nearly medial, 24-33 pairs on fully fertile pinnae, round, not impressed. Indusium reniform, with open sinus, attached at sinus.

Distribution - Indochina, throughout Malesia, to Queensland and Pacific.

Habitat \& Ecology - Usually at low elevations (sea level to $500 \mathrm{~m}$, rarely to $1000 \mathrm{~m}$ ), at forest margins and other disturbed places, often in coconut plantations, apparently preferring light shade, terrestrial, only rarely reported as epiphyte.

Note - Nephrolepis hirsutula differs from N. brownii (N. multiflora auct.), with which it has been extensively confused, in the sori placed less close to the margin, sometimes nearly medial; the dense, rufous rachis scales with very strongly dentate acumen; and the glabrous upper surface of costae. In contrast, $N$. brownii has usually sparser, paler rachis scales, with a longer, nearly always entire narrow apex. The combination of the rufous, dense, rachis indument and glabrous upper surface of the costae is characteristic for $N$. hirsutula, while the position of the sori is more variable. In case of doubt, the glabrous upper costa-surface is usually decisive.

\section{Nephrolepis lauterbachii H. Christ - Fig. 1k; Map 3; Plate 2e}

Nephrolepis lauterbachii H. Christ (1901) 456. - Type: Lauterbach 578 (P? n.v.), New Guinea. Nephrolepis humatoides Alderw. (1924) 33. - Type: Lam 2047 (BO), New Guinea.

Habit, rhizome morphology. Plants forming tufts of 5 or 6 fronds. Runners often proliferous, $0.5-1 \mathrm{~mm}$ thick (or thinner), branching angle narrow. Scales on runners sparse, spreading. Tubers absent. Fronds $25-34$ by $3-4 \mathrm{~cm}$, stipe $3-8 \mathrm{~cm}$ long. Lamina base strongly reduced, tapering over $8-10 \mathrm{~cm}$, reduced basal pinnae $0.9-1.1 \mathrm{~cm}$ distant, middle pinnae straight. Sterile pinnae $1.4-2$ by $0.3-0.5 \mathrm{~cm}$, leathery, base fully one-sided, basiscopic base narrowly cuneate, acroscopic base emarginate, cuneate or truncate, distinctly auricled, margin in basal part crenate, towards apex deeply dentate or incised, apex rounded or obtuse. Fertile pinnae 2 by $0.3-0.4 \mathrm{~cm}$, more sinuose between the sori than the sterile pinnae. Indument. Basal scales peltate or type of attachment indistinct, spreading, 4 by $0.25 \mathrm{~mm}$ (or less), central part light brown, dull, margin not hyaline, in basal part irregularly lacerate, in acumen entire, without glands, apex acumen narrow, often sinuous, tapering to a long narrow apex. Rachis scales sparse (often caducous), with a well-developed protracted acumen, spreading, dark (distinctly darker than the basal scales), acumen entire. Scales on lamina absent. Hairs on lamina absent. Sori submarginal or medial, elongated. Indusium lunulate, attached at broad base.

Distribution - Restricted to New Guinea, Moluccas and the Solomon Islands.

Habitat \& Ecology - At middle elevations, 900-2200 m, rarely at lower altitudes, from $250 \mathrm{~m}$ upwards, epiphytic or epilithic, in montane forest, often mossy or ridge forest.

Notes - Typical $N$. lauterbachii has small pinnae $(<2 \mathrm{~cm}$ long), with a sinuous upper margin, at least the middle pinnae distinctly dimidiate, with the attachment at the basal corner. Often the upper pinnae are caducous, therefore plants often have long whip-like bare rachises in older fronds. Although runners are frequently collected, bulbils are very rarely present, and then very small. Many collections have young plantlets at more or less regular intervals on main runners that are slightly thicker than the other ones. 
Nephrolepis lauterbachii can best be distinguished from $N$. cordifolia by the rachis scales, which are distinctly darker than the basal scales. In $N$. cordifolia, rachis scales and basal scales have the same pale to light brown colour. For the distinction from the South American N. pectinata, see under that species.

\section{Nephrolepis obliterata (R. Br.) J. Sm. - Fig. 1e; Map 4; Plate 2i}

Nephrolepis obliterata (R. Br.) J. Sm. (1842a) 197; Fée (1852) 319. - Nephrodium obliteratum

R. Br. (1810) 148. - Aspidium obliteratum Spreng. (1827) 99. - Arthropteris obliterata (R. Br.)

J. Sm. (1866) 163; (1875) 225. - Type: Banks s.n. (BM), Australia.

?Nephrolepis saligna Carruth. (1873) 361. - Type: Seemann 743 (BM), Fiji.

Habit, rhizome morphology. Plants forming tufts of 3 or 4 fronds. Runners 1-2 mm thick, branching angle divaricate. Scales on runners very sparse or sparse, appressed or spreading. Tubers absent. Fronds $100-170 \mathrm{~cm}$ long (or more), $12-33 \mathrm{~cm}$ wide, stipe $36-80 \mathrm{~cm}$ long. Lamina base truncate, tapering over $20-40 \mathrm{~cm}$, reduced basal pinnae $4-8 \mathrm{~cm}$ distant, middle pinnae slightly to distinctly falcate. Sterile pinnae 6-15 by $1.3-2.4 \mathrm{~cm}$, herbaceous, thick, base strongly unequal, basiscopic base rounded, acroscopic base cuneate or truncate, not auricled, margin in basal part crenate, apex acuminate or caudate, cauda to $3 \mathrm{~cm}$ long. Fertile pinnae $7-17$ by $0.9-2.1 \mathrm{~cm}$, more strongly dentate between the sori and more gradually narrowed than the sterile pinnae to an acute apex without a distinct cauda. Indument. Basal scales peltate, appressed (rather sparse), 2.5 by $1 \mathrm{~mm}$, central part dark brown, dull, hyaline margin wide, distinct, fimbriate in basal part, marginal glands absent. Transition to rachis scales abrupt. Rachis scales very sparse, without a distinctly protracted acumen, appressed and often very inconspicuous, hyaline. Scales on lamina absent. Hairs on lamina absent, costa absent. Sori marginal (often on teeth), 30-45 pairs on fully fertile pinnae, round. Indusium reniform, with narrow sinus or reniform, with open sinus, attached at sinus.

Distribution - Moluccas, New Guinea, New Britain, Solomon Islands, Vanuatu, New Caledonia, Pacific Islands: Carolines. Australia: Queensland. Any reports from Fiji and Samoa are doubtful: None of the specimens seen could be unambiguously identified as this species.

Habitat \& Ecology - Usually at low elevations, from sea level to $300 \mathrm{~m}$, occasionally to $1000 \mathrm{~m}$. In various types of forests or plantations, in mangroves and swamp forest; often abundant in undergrowth, in clearings or on riverbanks and forest margins, also as low epiphyte on tree trunks or on fallen trees.

Notes - The name $N$. saligna has been frequently applied to specimens of this species, but its application is not certain. Of the available type material, one specimen (Seemann 7530, marked as type of N. saligna in K) is N. brownii, two others (Banks \& Solander s.n., s.d.; Home s.n., 1853, Fiji, both BM) are N. biserrata, a fourth specimen (Seemann 743, BM) is sterile and lacks the basal scales necessary for a reliable identification.

The name Nephrodium obliteratum $\mathrm{R}$. Br. has often been taken be a synonym of Arthropteris palisotii (Desv.) Alston, however, the type (Banks s.n., BM) clearly is a Nephrolepis species.

Nephrolepis obliterata is not easy to characterize. It usually has quite large pinnae, with nearly marginal sori. Characteristically, they are gradually narrowed from close 
to the base upwards, and gradually falcate from $\pm 1 / 2$, sometimes all the way from the base. The best distinguishing characters are in the indument. The indument of N. obliterata differs from that of $N$. biserrata, with which it has often been confused, in the scales at the base of stipe being closely appressed, with a rather sharp transition to sparse, appressed, very translucent and inconspicuous peltate scales upwards on the stipe and on the rachis. The very sparse, inconspicuous rachis scales and the absence of hairs on the costae also distinguish it from $N$. davallioides, $N$. brownii or $N$. falcata. In addition, $N$. brownii has usually less distinctly falcate pinnae, and those of $N$. falcata are usually smaller.

\section{Nephrolepis pectinata (Willd.) Schott - Map 3c}

Nephrolepis pectinata (Willd.) Schott (1834) ad. pl. 3; Pic. Serm. (1969) 272; Nauman (1992) 288; Mickel \& A.R. Sm. (2004) 407. - Aspidium pectinatum Willd. (1810) 223. - Nephrodium pectinatum (Willd.) Sweet (1826) 462; Link (1833) 125. - Type: Willdenow 19753 (Willdenow herb., B), without locality.

Nephrolepis schkuhrii Fée var. minor Fée (1852) 319. - Type: Linden 1881 (G), Cuba.

Habit, rhizome morphology. Plants epiphytic, epilithic or terrestrial, forming tufts of 3-7 fronds. Runners 0.1-0.4 mm thick, branching angle narrow. Scales on runners very sparse or sparse, appressed or spreading. Tubers absent. Fronds $14-81$ by 1-6 $\mathrm{cm}$, stipe $1-15 \mathrm{~cm}$ long. Lamina base strongly reduced, tapering over $10-20 \mathrm{~cm}$, basal pinnae $0.3-1.3 \mathrm{~cm}$ long, $1-1.5 \mathrm{~cm}$ distant, middle pinnae straight to distinctly falcate (rarely). Sterile pinnae herbaceous, thin, base strongly unequal to fully one-sided, basiscopic base narrowly cuneate or cuneate, acroscopic base truncate or rounded, distinctly auricled, margin in basal part entire, towards apex dentate, apex rounded or obtuse. Fertile pinnae $0.7-2.9$ by $0.3-0.8 \mathrm{~cm}$, otherwise similar to sterile ones. Indument. Basal scales peltate, $1-3.2$ by $0.2-0.7 \mathrm{~mm}$, central part dark brown or blackish, dull, margin not hyaline, in basal part irregularly lacerate, dentate or ciliate, in acumen denticulate to ciliate, marginal glands absent. Rachis scales sparse, light brown, appressed or spreading, with a well-developed protracted dentate or ciliate acumen. Scales on lamina absent. Hairs on lamina and costa absent. Sori submarginal or medial, 3-6 pairs on fully fertile pinnae, round or elongated, not impressed. Indusium lunulate or broad, attached at broad base.

Distribution - Cuba, Hispaniola, Jamaica, throughout Central America, southern Mexico, western South America south to Peru, Bolivia (one specimen), Brazil (one specimen, without locality).

Habitat \& Ecology - Occurs in a variety of habitats, from dense to open sites, frequently on or among rocks. From sea level to $2470 \mathrm{~m}$, mainly between 500-1500 m.

Notes - Nephrolepis pectinata is very similar to the Palaeotropical N. lauterbachii, but can be distinguished from that species by the lighter and more deciduous rachis scales (persistent only in tufts near the pinnae-bases, and these strongly lacerate), and the runners not or only rarely bearing small plants. In addition, the rhizome of $N$. pectinata tends to become horizontal and more or less dorsiventral with age. It may be confused with $N$. cordifolia and $N$. occidentalis, especially the distinction from $N$. cordifolia may sometimes give problems, as the only constant character appears to be the character of the pinna shape and the absence of tubers, the presence of which is not always clear in specimens of $N$. cordifolia. 
Two cytotypes have been reported for this species, and according to Naumann (1985) the cytological polymorphism is correlated with a morphological one, the diploid form being distinctly larger than the more widespread tetraploid one.

\section{Nephrolepis pendula (Raddi) J. Sm. - Map 6}

Nephrolepis pendula (Raddi) J. Sm. (1842a) 197; Fée (1852) 319; Brack. (1854) 211; Nauman (1992) 288; Mickel \& A.R. Sm. (2004) 408. - Aspidium pendulum Raddi (1819) 11. - Nephrodium pendulum (Raddi) Desv. (1827) 252. - Nephrolepis tuberosa (Bory) C. Presl var. pendula (Raddi) Hook. (1862) 151. - Nephrolepis pectinata (Willd.) Schott subsp. pendula (Raddi) Jenman (1896) 261. - Type: Raddi s.n. (FI, K, US), Brasil.

Nephrodium crenatum Desv. (1827) 252. - Nephrolepis crenata (Desv.) Fée (1845) 14, pl. 1, f. 19.

- Type: Anon. s.n. (P n.v., photograph BM).

Habit, rhizome morphology. Plants epiphytic, epilithic or terrestrial (most frequently epiphytic), forming tufts of 3-5 fronds. Runners $0.2-0.8 \mathrm{~mm}$ thick, medium to dark brown, black or purple-black, wiry. Scales on runners very sparse, loosely spreading. Tubers absent. Fronds $25-225$ by $2-14 \mathrm{~cm}$, stipe $2-36 \mathrm{~cm}$ long. Lamina base reduced, tapering over $15-25 \mathrm{~cm}$, basal pinnae $0.5-1.9 \mathrm{~cm}$ long, $1.5-3 \mathrm{~cm}$ distant, middle pinnae slightly to distinctly falcate. Sterile pinnae herbaceous, thick, base slightly to strongly unequal, basiscopic base cuneate, truncate or rounded, acroscopic base truncate or cordate, not to distinctly auricled, margin in basal part entire or crenate, towards apex serrate or dentate, apex rounded or acute. Fertile pinnae $1.6-6.8$ by $0.4-1.3 \mathrm{~cm}$, otherwise similar to sterile ones. Indument. Basal scales peltate, appressed or spreading, $0.6-4$ by $0.1-0.8 \mathrm{~mm}$, central part dark brown or blackish, shining, hyaline margin absent or narrow, marginal glands absent, margin in basal part dentate or ciliate, in acumen dentate or ciliate. Rachis scales very sparse or sparse, without a distinctly protracted acumen, appressed, hyaline or light brown. Scales on lamina absent. Hairs on lamina and costa absent. Sori submarginal, 7-12 pairs on fully fertile pinnae, round or elongated, not impressed. Indusium lunulate or broad, attached at broad base. Spores with coarse irregular ridges.

Distribution - Throughout the Neotropics from Cuba to Brazil.

Habitat \& Ecology - Most frequently epiphytic, but also terrestrial or epilithic, in generally moist habitats such as cloud forests, occasionally on roadsides or very open habitats. Sea level to $4300 \mathrm{~m}$.

Note - A characteristically glabrous species with long pendulous fronds, lustrous stipes, without scales whatsoever in many specimens (where present, with very long marginal appendages), with nearly marginal sori, and with indusia with broad base or wide sinus.

\section{Nephrolepis radicans (Burm.f.) Kuhn - Map 5; Plate 2a}

Nephrolepis radicans (Burm.f.) Kuhn (1869) 285; Backer \& Posth. (1939) 93; Copel. (1958) 185; Holttum (1968) 381; Tagawa \& K. Iwats. (1985) 176. — Polypodium radicans Burm.f. (1768) 233, pl. 66, f. 3. - Type: Pryon s.n. (n.v.), Java.

Nephrolepis clementis H. Christ (1908) 272; Copel. (1958) 185. - Type: Clemens 920 (P), Philippines.

Lepidonevron volubile Fée (1852) 301. - Nephrolepis volubilis (Fée) J. Sm. (1841) 413; Kunze (1848a) 236; C. Presl (1851) 44. - Type: Cuming 37 (BM, P), Philippines. 
Aspidium obtusifolium Willd. (1810) 231; Blume (1828) 145. - Nephrodium obtusifolium (Willd.)

C. Presl (1830) 32. - Nephrolepis obtusifolia (Willd.) C. Presl (1836) 80; Brack. (1854) 210.

- Type: Klein s.n. (Willdenow herb. 18756, B).

Habit, rhizome morphology. Plants terrestrial, forming tufts of 3-5 fronds. Runners tendril-like, proliferous or free, $1 \mathrm{~mm}$ thick, branching angle divaricate or straight. Scales on runners very sparse or sparse, appressed, spreading or (some) squarrose. Tubers absent. Fronds $94-102$ by $7.5-10 \mathrm{~cm}$, stipe $12-14 \mathrm{~cm}$ long. Lamina base strongly reduced, tapering over $20-35 \mathrm{~cm}$, basal pinnae $0.5-1 \mathrm{~cm}$ long, $2.5-3 \mathrm{~cm}$ distant, middle pinnae straight or slightly falcate. Sterile pinnae $3.5-4$ by $0.9-1 \mathrm{~cm}$, herbaceous, thick, base slightly to strongly unequal, basiscopic base rounded, acroscopic base truncate, slightly auricled, margin in basal part crenate, apex rounded or obtuse. Fertile pinnae $4.5-6$ by $0.7-0.8 \mathrm{~cm}$, otherwise similar to sterile ones. Indument. Basal scales peltate, appressed, 2 by $0.7 \mathrm{~mm}$, central part dark brown or blackish, shining, margin in basal part hyaline, ciliate, in acumen pale brown (often abruptly distinct from the dark central part), entire or denticulate; strongly elongated, lightly coloured marginal glands present around the scale. Rachis scales sparse or dense, without a distinctly protracted acumen, appressed (often somewhat bullate when dry), light brown. Scales on lamina sometimes present, very few, appressed, on lower surface. Hairs on lamina absent, on costa constantly present (also on lower surface, usually sparse). Sori submarginal, 20-23 pairs on fully fertile pinnae, round, not impressed. Indusium reniform, with open sinus, attached at sinus.

Distribution - India, Burma, Thailand, Vietnam, Malesia to Moluccas, New Guinea, New Caledonia.

Habitat \& Ecology - At low elevations to $1000 \mathrm{~m}$, terrestrial and scrambling over shrubs or trees, on waste ground, in belukar, often in swamps or on riverbanks.

Note - One of the most distinct and easily recognizable species of Nephrolepis, with a unique growth form. In $N$. radicans the runners are strongly differentiated and three distinct types can easily be distinguished on a single plant. Thick runners which, in contrast to normal runners, tend to grow upwards, form dense scrambling thickets, attached to supporting vegetation by tendril-like runners originating on the frond-bearing rhizomes. These frond-bearing rhizomes are short, densely scaly side branches, each apparently with a limited growth and with a limited number of fronds; typically only 3 or 4 well-developed ones present at the same time. In addition, they also bear long runners which bear roots wherever they come into contact with a suitable substrate. Apart from this distinct growth form, this species is easily recognizable by the obtuse or rounded pinnae and the scales on the rachis of the fronds that are somewhat bullate when dry.

\section{Nephrolepis rivularis (Vahl) Mett. ex Krug - Map 6}

Nephrolepis rivularis (Vahl) Mett. ex Krug (1897) 122; Proctor (1989) 263; Nauman (1992) 288; Mickel \& A.R. Sm. (2004) 408. - Polypodium rivulare Vahl (1807) 51. - Type: Ryan s.n. (C), Montserrat.

Aspidium sesquipedale Willd. (1810) 230. - Aspidium hoffmanseggi (Willd.) Poir. (1817) 509 (nom. illeg.). - Nephrodium hoffmanseggi Desv. (1827) (nom. illeg.). - Nephrolepis sesquipedalis (Willd.) C. Presl (1836) 79. - Lepidonevron sesquipedale (Willd.) Fée (1869) 148. - Type: Hoffmansegg s.n. (Willdenow herb 19755, B), Brasil. 
Aspidium eminens Wikstr. (1826) 434. - Type: Forsström s.n. (S-PA), Guadeloupe.

Nephrolepis neglecta Kunze (1839a) 149. - Type: Schiede s.n. (LZ, destroyed, iso NY?), teste Mickel \& A.R. Sm. (2004).

Nephrolepis valida Kunze (1848b) 229. - Type: Kegel 1379 (GOET n.v.), Surinam.

Nephrolepis intermedia Sodiro (1893) 57 (nom. illeg. non Fée, 1857, see under N. undulata). - Type: Sodiro s.n. (K, US), Ecuador.

Habit, rhizome morphology. Plants epiphytic, epilithic or terrestrial, forming tufts of 3 or 4 fronds. Runners $0.2-0.9 \mathrm{~mm}$ thick, branching angle narrow. Scales on runners sparse or dense, spreading or squarrose. Tubers absent. Fronds $39-165$ by $5-13 \mathrm{~cm}$, stipe $6-45 \mathrm{~cm}$ long. Lamina base reduced, tapering over $20-30 \mathrm{~cm}$, basal pinnae $0.7-2.6$ $\mathrm{cm}$ long, 2.5-3 cm distant, middle pinnae distinctly falcate. Sterile pinnae herbaceous, base strongly unequal, basiscopic base cuneate, acroscopic base truncate, distinctly auricled, margin in basal part entire or crenate, towards apex more deeply dentate, apex obtuse or acute. Fertile pinnae $2.8-6.7$ by $0.5-1.1 \mathrm{~cm}$, otherwise similar to sterile ones. Indument. Basal scales peltate, spreading or squarrose, $2-6.5$ by $0.4-1 \mathrm{~mm}$, central part rufous or dark brown, shining, hyaline margin narrow, usually very distinct even when narrow, or absent, margin in basal part irregularly lacerate or dentate, in acumen dentate or ciliate, marginal glands absent. Rachis scales dense or very dense, rufous or dark, with a well-developed protracted, spreading or squarrose, entire, very narrow, filiform acumen. Scales on lamina sometimes present. Hairs on lamina sometimes present, on costae absent. Sori submarginal or medial, 11-20 pairs on fully fertile pinnae, round, slightly impressed. Indusium reniform, with narrow sinus, attached at sinus.

Distribution - Throughout the Neotropics, from Cuba and Southern Mexico south to Bolivia, east to the Lesser Antilles and Brazil.

Habitat \& Ecology - Commonly terrestrial or epiphytic, in forested, often moist habitats, at low to middle elevations, sea level to $2200 \mathrm{~m}$.

Note - A distinct species, with submedial indusia that are firm, dark, and round with a very narrow sinus, sometimes appearing peltate (and occasionally reported as such). Rachis often with a peculiar, 'scabrous' look, caused by the persistent scales, with spreading to squarrose appendages (not only the long filiform acumen, but also the appendages on the lacerate base are well-developed and erecto-patent).

\section{Nephrolepis undulata (Afzel.) J. Sm. - Map 3}

Nephrolepis undulata (Afzel.) J. Sm. (1845) 35; Pic. Serm. (1969) 273; Proctor (1989) 261; Nauman (1992) 288; Verdc. (2001) 5; Mickel \& A.R. Sm. (2004) 409. - Aspidium undulatum Afzel. in Sw. (1801) 32; Sw. (1806) 45. - Nephrolepis tuberosa (Bory) C. Presl var. undulata (Afzel.) Kuhn (1868) 156. - Nephrolepis cordifolia (L.) C. Presl var. undulata (Afzel.) C. Chr. (1906) 453, 455. - Nephrolepis undulata var. undulata (Afzel.) Verdc. (2001) 5. - Type: Anon. s.n. (BM).

Nephrolepis occidentalis Kunze (1844) 243 [= 343]. - Nephrolepis cordifolia (L.) C. Presl var. occidentalis (Kunze) Krug (1897) 121. - Nephrolepis pectinata (Willd.) Schott var. occidentalis (Kunze) Urb. (1925) 316. - Type: Roemer 27 (BM? n.v.), Mexico.

Nephrolepis delicatula M.J. Decne. (1844) 178, t. 179; Pic. Serm. (1969) 275; Tagawa \& K. Iwats. (1985) 174. - Nephrolepis tuberosa (Bory) C. Presl var. delicatula Hook. (1846) 151. Nephrolepis undulata (Afzel.) J. Sm. var. delicatula (M.J. Decne.) Verdc. (2001) 7. - Type: Jacquemont 598 (K, P), India.

Nephrolepis intermedia Fée (1857) 32 (non Sodiro 1893). - Type: Schaffner 447 (K), Mexico.

Nephrolepis pluma T. Moore (1878a) 588, f. 108. - Type: Anon. s.n. (K).

Nephrolepis glabra Copel. (1906) 146; (1958) 186. - Type: Copeland 1819 (KYO, MICH, P, SING), Philippines. 
Nephrolepis filipes H. Christ (1909b) 213. - Type: Gillet 3126 (P), Congo.

Nephrolepis cordifolia (L.) C. Presl var. compacta Bonap. (1923) 265; Pic. Serm. (1969) 273. - Type: Bequaert 3018 (BR, teste Pichi Sermolli).

Nephrolepis paucifrondosa J.F.R. Almeida (1926) 51. - Type: J.H. Lace 4940 (K).

Habit, rhizome morphology. Plants forming tufts of 2 or 3 fronds. Runners $0.5-1 \mathrm{~mm}$ thick (or thinner), branching angle divaricate. Scales on runners very sparse or sparse, spreading. Tubers present. Fronds 50-90 cm long (or longer), 5-7 cm wide, stipe $6.5-15 \mathrm{~cm}$ long. Lamina base strongly reduced, tapering over $8-15 \mathrm{~cm}$, basal pinnae $0.6 \mathrm{~cm}$ long, $2-4 \mathrm{~cm}$ distant, middle pinnae straight to distinctly falcate. Sterile pinnae $2.9-3.2$ by $0.6-0.8 \mathrm{~cm}$, herbaceous, thin, base slightly unequal, strongly unequal or fully one-sided, basiscopic base cuneate or cordate, acroscopic base cordate, auricled (often dilated and crossing the rachis), margin in basal part crenate or dentate, towards apex dentate or deeply dentate, apex acute. Fertile pinnae $2.1-3.5$ by $0.5-0.7 \mathrm{~cm}$, the base often more distinctly one-sided and the margin more deeply dentate than the sterile pinnae. Indument. Basal scales peltate, spreading, 3.5 by $0.5 \mathrm{~mm}$, straw-coloured or hyaline, dull, margin in basal part irregularly lacerate with a few protrusions, in acumen entire, marginal glands absent. Rachis scales very sparse (persistent only around the pinna-bases), with a well-developed spreading, ciliate acumen, or completely dissected into narrow filaments, with hyaline or dark glandular apical cells. Scales on lamina absent. Hairs on lamina frequently present (very inconspicuous), on costa absent. Sori submarginal or medial, 6-10 pairs on fully fertile pinnae, elongated, slightly impressed. Indusium lunulate or broad, attached at broad base.

Distribution - Worldwide. Widespread in Africa and Tropical Central and South America. In Asia there is a distinct distributional centre from Indochina to Northern India, but N. undulata occurs scattered elsewhere: Malabar, Kerala, Madras, Philippines.

Habitat \& Ecology - Usually terrestrial, in grassland, brushwood or forest, or epilithic, on cliffs, lava flows or rocky outcrops, rarely indicated as epiphytic, altitude $300-2450 \mathrm{~m}$.

Notes - The name $N$. undulata has been applied traditionally to the form occurring in Africa, which is relatively robust. The smaller forms from Asia have been named $N$. delicatula, or $N$. paucifrondosa, while the forms from the Americas were distinguished as N. occidentalis by Nauman $(1985,1992)$.

Nephrolepis undulata is here distinguished from N. cordifolia by the seasonal mode of growth, with new fronds sprouting each season from underground tubers. In most cases, no more than two well-developed fronds develop in a single season, and in many cases collections contain only plants with a single frond. The first sprouting frond in $N$. undulata is usually the largest one and remains connected to the tuber by a subterraneous, somewhat sinuous, glabrous stem. If other fronds develop, they do so from a bud that appears to be in a lateral position on the base of the stipe of the first frond, not from a distinct rhizome. Despite the usually slender stature of the tufts, individual fronds, especially the first one, can be quite large. Apart from this characteristic growth form, this species can usually also be distinguished from $N$. cordifolia by the more glabrous stipe and rachis, the basal part of which is often conspicuously thicker than in $N$. cordifolia, and the, especially in comparison to the stipe, thin runners originating from the rhizome bud. According to Fraser-Jenkins (pers. comm.) the tubers of speci- 
mens in Nepal are more elongated than those of $N$. cordifolia. In African material, a large number of mature tubers seen are also elongated, but this is not always the case. Despite these differences, the possibility cannot be completely excluded that this description is based on an ecologically correlated set of characters that have developed independently in separate populations of $N$. cordifolia, in response to the requirements imposed by a strongly seasonal climate.

\section{HYBRIDS AND SUSPECTED HYBRIDS}

\section{Nephrolepis arida D.L. Jones}

Nephrolepis arida D.L. Jones (1988) 474. - Type: Jones 1598 (holo DNA n.v.; iso K), Australia.

The duplicate in $\mathrm{K}$ of the type of this species is a well-developed plant, with basal scales somewhat thickened in the best developed tuft, and spreading sideways away from the stipe exactly like in $N$. biserrata. Sori are irregularly shaped, most reniform, but some are more athyrioid with unequal base, and none contain well-developed sporangia. On the whole, the characters of this specimen are consistent with a hybrid origin involving almost certainly $N$. biserrata and possibly $N$. cordifolia, but considering that the specimens occur in sites where the growth conditions for Nephrolepis appear to be marginal, it may also represent a somewhat aberrant specimen of the former.

\section{Nephrolepis $\times$ averyi Nauman}

Nephrolepis $\times$ averyi Nauman (1979b) 69. - Type: Nauman et al. 635 (holo US n.v.; iso A), Florida.

$=$ Nephrolepis biserrata $\times N$. exaltata, intermediate between the putative parents.

Distribution - Largely Caribbean: Florida, Cuba, Jamaica, Puerto Rico, Mexico.

Habitat \& Ecology - In forested, often moist habitats or in disturbed relatively dry habitats, at sea level to middle elevations (520 m).

Note - Only found in mixed populations of the parent species.

\section{Nephrolepis $\times$ copelandii W.H. Wagner et al.}

Nephrolepis $\times$ copelandii W.H. Wagner et al. (1999) 185. - Type: Wagner et al. 91044 (MICH n.v.), Hawaii.

$=$ Nephrolepis cordifolia $\times N$. brownii, intermediate between the putative parents.

Distribution - So far found on Hawaii only, but can be expected to occur throughout the common range of both parents as a byproduct of the expansion of $N$. brownii.

\section{Nephrolepis $\times$ hippocrepicis Miyam., hybr. nov.}

Planta hybrida, differt ab N. cordifolia squamis stipitis margine ciliatis lineo-lanceolatis; ab $N$. biserrata pinnis triangularis, supernis latis auriculatis, indusis lunulatis vel reniformis. Sporae abnormales et abortivae. - Typus: Miyamoto \& Nakayama s.n. (holo TUAT; iso B, BISH, BM, K, MICH, NY, P, TAI), Ryukyu Islands, 5 March 1985.

Distribution - Ryukyu Islands, possibly elsewhere where the two putative parents occur together. 
Note - Putative hybrid between Nephrolepis cordifolia and N. biserrata. This hybrid is very similar to $N$. exaltata, and one specimen was in fact identified by Nauman as such. However, N. exaltata does not occur in Asia. Nephrolepis $\times$ hippocrepicis can be distinguished from $N$. biserrata by the distinctly triangular pinnae with auriculate acroscopic base, from $N$. cordifolia by the narrower sinus of the indusia and the ciliate stipe scales. The spores of all specimens examined are abnormal. A specimen with a somewhat similar morphology was collected in Thailand (Umaporn Intern s.n. 1999, Doi Sutep near Puping Palace, L).

Specimens examined:

JAPAN. Ryukyu Islands: Okinawa Island, Yona Exp. Forest of Ryukyu Univ. Yona, Kunigamison, 100-200 m: Miyamoto \& Nakayama s.n., 5 March 1985, Miyamoto \& Nakayama 1407, 1408, 1409, 1412, 1413, 1414 (TUAT); Iwatsuki et al. s.n. (KYO); Miyako Island, Ohgami: Miyagi et al. s.n. (KYO).

\section{Nephrolepis hirsutula $\times$ N. brownii}

These two species are occasionally difficult to distinguish and confusion may be due to occasional hybridization.

\section{Nephrolepis $\times$ medlerae W.H. Wagner et al.}

Nephrolepis $\times$ medlerae W.H. Wagner et al. (1999) 183, f. 28. - Type: Wagner et al. 91025 (MICH n.v.), Hawaii.

Putative hybrid between $N$. exaltata and N. multiflora, intermediate between the putative parents; sterile, partly with irregularly scattered sori.

Distribution - So far found on the Hawaiian Islands only (Oahu, Maui, Kauai), but can be expected to occur throughout the common range of both parents as byproduct of the expansion of $N$. brownii.

\section{Nephrolepis $\times$ pseudobiserrata Miyam., hybr. nov.}

$N$. biserrata $\times N$. brownii. Planta hybrida, differt ab $N$. biserrata sqamis stipitis et rachibus ovato-lanceolatis valde numerosis adpressis margine ciliatis, pinnis basibus supernis auriculatis; ab $N$. brownii soris submargine, indusis majus rotund-reniformibus, pinnis inferior vix reductis, textura laminae coriaceior. - Typus: Miyamoto \& Nakayama 1444 (holo TUAT; iso BISH, BM, K, MICH, NY, TAI), Ryukyu Islands, 11 March 1985.

Plants epiphytic or terrestrial. Rhizome erect to ascending, scales densely set, narrowly ovate, $6-9$ by $1.8-2 \mathrm{~mm}$, dark-brown, lustrous, margin densely ciliate. Stipes $30-50$ $\mathrm{cm}$ long; basal scales appressed, narrowly ovate, $5-7$ by $1.3-2 \mathrm{~mm}$, centrally darkbrown, lustrous, margin, pale brown, ciliate. Lamina lanceolate; pinnae 40-70 pairs, linear, $3-12$ by $1-2.5 \mathrm{~cm}$, margin dentate, acroscopic base auriculate, basiscopic base rounded or cuneate. Indument. Rachis scales dense, appressed, 2-4 by $0.3-0.4 \mathrm{~mm}$. Sori submarginal, indusia round-reniforme. Spores abortive.

Distribution - Ryukyu Islands, but may be found elsewhere as a result of the expansion of the range of $N$. brownii.

Specimens examined:

JAPAN. Ryukyu Islands: Ishigaki Isl., Sukieda-Yoshihara, 30 m: Miyamoto \& Nakayama 1444, 11 March 1985; Miyamoto \& Nakayama 1443, 1446, 1447, 1449-1451, 1454 (all BISH, BM, MICH, 
NY, TAI, TUAT); Ishigaki Isl., Ishigaki city, Mt Banna-dake, 80-100 m, Miyamoto \& Nakayama 1189-1203 (TUAT).

\section{CULTIVARS AND MONSTROSITIES}

The following enumeration of spontaneous and/or cultivated forms is compiled from herbarium sources mainly and is not intended as an exhaustive survey of Nephrolepis in cultivation.

\section{Nephrolepis biserrata}

Two plants with repeatedly furcate pinnae have been collected on Celebes and Java (Rachmat 122, Bakhuizen 6515), both possibly from cultivation. A similarly furcate form was described as $N$. davallioides var. furcans by Moore (1873). Furcate forms of $N$. biserrata are quite regularly fertile, which may serve to distinguish them from similar forms of $N$. exaltata. A form with irregularly cristate/furcate pinnae was collected on Sarawak (Dyak s.n., Dec. 1908, Bidi, BM).

One plant with a frond with highly dichotomously divided, plumose pinnae alongside a normal sterile frond collected in Thailand (Eryl Smith 2736, 3 Jan. 1925, K, Setun, Puket, $\mathrm{nr}$ sea level on a hill) was originally identified as $N$. exaltata but may belong to N. biserrata.

A sterile form with irregularly lacerate pinnae was collected near Guayaquil (Spruce s.n., Dec. 1860, K).

A form with very long (up to $2 \mathrm{~cm}$ long and $1 \mathrm{~cm}$ wide) acroscopic extensions ('auricles') at the pinna-bases was collected in Hainan (H. Fung 20043, 26-29 April 1932, BM, Ling Shui district BM). A similar plant is depicted by Mettenius (1856), plate 26, as N. platyotis.

\section{Nephrolepis brownii}

Nephrolepis mayii (Anon., Gard. Mag. Bot. (1903) 688, 705) and N. westonii (Anon., Gard. Chron. 34 (1903) 309), both crested varieties, appear to derive from N. brownii, judging by plants cultivated collected under these names in Kew. An unnamed bipinnate form is present in $\mathrm{K}$ with some collections from plants in cultivation in Bangalore over more than a century (collections from 1886 and 1962/3), this form also belongs to $N$. brownii.

\section{Nephrolepis exaltata}

Most of the Nephrolepis cultivars currently in cultivation derive from Nephrolepis cv. 'bostoniensis', which is conventionally associated with N. exaltata (Benedict, 1916a). An overview of the most frequently cultivated forms is given by Hoshizaki \& Moran (2001).

Morton (1958) suggested that 'bostoniensis' was possibly a hybrid with N. exaltata as one parent. Its constant sterility, morphological instability and vegetative vigour indicate a hybrid origin, but there is no reason to assume that $N$. exaltata is involved as parent, when we consider that $N . \times$ hippocrepicis, which originated well outside the distribution area of $N$. exaltata, exactly mimics the morphology of $N$. exaltata, and another such hybrid may equally well have given rise to 'bostoniensis'. 


\section{Nephrolepis falciformis}

Despite the fact that this species appears to be more restricted to forest than many of the other species of Nephrolepis, it appears to be cultivated in gardens and along roadsides in Java, with collections from the Botanic Garden in Bogor going back to the early part of the 20th century (collected a number of times by Raciborski).

\section{Nephrolepis hirsutula}

Nephrolepis hirsutula appears to have been the species to give rise to most cultivated forms before the advent of 'bostoniensis'. Many of these forms have been collected from several places within the range of $N$. hirsutula, sometimes without any indication of being cultivated (e.g., Lauterbach 309, 1890, New Britain, 800 m; Hahn s.n., 1905, Yabim Isl., New Guinea).

A form with irregularly bipinnatifid fronds appears to have been extensively cultivated in the 18th century. It was collected as cultivated in Mangalore, South India (Anon. s.n., 1904, P), Java (Buysman 2286, Mousset s.n., 1910, L), Hawaii (Faurie s.n., 1909, P); New Hebrides (Richards s.n., before 1873, hb. Macleay, K), Duke of York Island (Betche s.n., 1871, cult? notes unreadable, P); Papua New Guinea (Croft 854).

Specimens with marginally proliferous pinnae were collected on the Philippines (G. Wallis s.n., 1871, Luzon, P) and on Sumatra (Korthals s.n., P).

A lacerate form was collected in 1927 from a cultivated plant in Bandung (Wisse 1182, BO), and a similar form was collected from cultivation in Surabaja in 1923 (Dorgelo 1941, BO) and again in 1934 (Anon. s.n., BO).

A form with irregularly lacerate pinnae was collected on New Britain in 1887 (Parkinson s.n., K).

Forma 'tripinnatifida' (Baker, 1887: 476, f. 90-91) is a finely divided form reported to be introduced from Fiji Islands.

A poorly fertile form with regularly furcate pinnae was described as Nephrodium multifidum A. Rich.

Nephrolepis duffii: Usually, N. duffii is, following Goebel (1907) and Morton (1958), taken to be a (sterile) form of $N$. cordifolia. However, the original specimens we have seen are for the largest part clearly forms of $N$. hirsutula. This is confirmed by a fertile plant growing in a nursery in Singapore, collected by M.G. Price (Price s.n., BO). The sori of this plant are clearly not the lunulate sori characteristic of $N$. cordifolia, and basal scales and rachis indument also suggest an origin in N. hirsutula. Similar fertile plants in cultivation in a completely different location are described by Tryon (1962). Although N. duffii represents a very distinct form, with short, orbicular pinnae and furcate rachises, there may be different origins in different species of Nephrolepis. The tuberous forms assigned to $N$. duffii by Morton (1958) probably have their origin in N. cordifolia and a similar plant collected by Forrest in Burma (Forrest 12174, BM, March 1914, "Hills around Prome Lower Burma") appears to have originated in $N$. brownii. Cultivated forms currently being distributed under the name $N$. duffii appear to be derived from $N$. 'bostoniensis'. The original $N$. duffii is characterized by small, deeply furcate or paired pinnae, while most of the 'lookalike' forms have single pinnae. 


\title{
EXCLUDED SPECIES
}

\author{
Nephrolepis iridescens Alderw. (1915) 20. - Type: Jaheri s.n. (holo BO), Key Islands \\ = Asplenium sp.
}

\section{ACKNOWLEDGEMENTS}

We are grateful to the directors and curators of the following herbaria for allowing us to study material: A, B, BISH, BM, BO, BRI, E, F, K, KYO, L, MICH, NSW, NY, P, SING, TI, TNS, TUAT, U, US, WAG.

We gratefully acknowledge the Hortus Botanicus Leiden for its cooperation in making living material available for study of the following species: Nephrolepis biserrata, N. brownii, N. cordifolia, $N$. davallioides, $N$. falcata, $N$. falciformis, $N$. lauterbachii, $N$. radicans; and Mr. Kaoru Kobayashi from Kagoshima tropical botanical garden, for his help in cultivating various species.

Descriptions for the taxa were prepared with the aid of the Delta package (Dallwitz,1980; Dallwitz et al., 1993, 1999).

A small part of this study was supported by a travel grant to PH from NWO (Netherlands Organization for Scientific Research) in 2001.

\section{REFERENCES}

Backer, C. A. \& O. Posthumus. 1939. Varenflora voor Java. 's Lands Plantentuin, Buitenzorg.

Baker, J.G. 1867. Synopsis Filicum. Robert Hardwicke, London.

Baker, J.G. 1887. Nephrolepis rufescens. Gard. Chron. 1887: 476

Ballard, F. 1955. A Nephrolepis from West Africa. Kew Bull. 1955: 467.

Bell, G.H. 1998. Nephrolepis. Flora of Australia 48. CSIRO, Melbourne.

Benedict, R.C. 1915. Nephrolepis: a description of the species and horticultural varieties, with a general discussion of the genus. In: Bailey's Standard Cyclopedia of Horticulture IV: 2131-2135.

Benedict, R.C. 1916a. Some horticultural fern variations. Amer. Fern J. 6: 8-15.

Benedict, R.C. 1916b. The origin of new varieties of Nephrolepis by orthogenetic saltation. Bull. Torrey Bot. Club 43: 207-234.

Benedict, R.C. 1922. The origin of new varieties of Nephrolepis by orthogenetic saltation. II. Regressive variation of reversion from the primary and secondary sports of Bostoniensis. Amer. J. Bot. 9: 140-157.

Bernhardi, J.J. 1803. Wahrscheinliche entdeckung der Befruchtungsart der Farrenkräuter. In: H.A. Schrader, J. Bot. 1801.

Blume, C.L. 1828. Enumeratio Plantarum Javae et Insularum adjacentium. Fasc. II. Van Leeuwen, Leiden.

Bojer, W. 1837. Hortus Mauritianus: 392. Aimé Mamarot \& Compagnie, Mauritius.

Bonaparte, R. 1918. Nephrolepis. Notes Ptéridologiques 7: 399.

Bonaparte, R. 1923. Nephrolepis. Notes Ptéridologiques 14.

Bory, J.B.G.G.M. 1804. Voyage dans les quatre prinicipales îles des mers d'Afrique. Buisson, Paris.

Bory, J.B.G.G. M. 1810. In: K.L. Willdenow, Species plantarum 5-1: 234. Nauk, Berlin.

Bory, J.B.G.G.M. 1833. Botanique. In: C.P. Bélanger, Voyage aux Indes Orientales: 50. Bélanger, Paris.

Brackenridge, W.D. 1854. United States Exploring Expedition. 16. Filices. Sherman, Philadelphia. Brause, G. 1913. Neue Farne Papuasiens. Bot. Jahrb. Syst. 49: 1-59.

Britton, N. 1918. Flora of Bermuda. Charles Scribner's Sons, New York.

Brown, E.D.W. \& F. B.H. Brown. 1931. Flora of Southeastern Polynesia. II. Pteridophytes. Bernice P. Bishop Mus. Bull. 89.

Brown, R. 1810. Prodromus Florae Novae-Hollandiae. Johnson \& Co., London. 
Brownsey, P. J. \& J.C. Smith-Dodsworth. 1989. New Zealand ferns and allied plants. David Bateman, Auckland.

Burman, N.L. 1768. Flora Indica. Haak \& Schreuder, Leiden, Amsterdam.

Carruthers, W. 1873. Filices. In: B.C. Seemann, Flora Vitiensis 10. London.

Cavanilles, A.J. 1801. Descripcion de las plantas. 1. Imprenta real, Madrid.

Christ, H. 1895. Filices Sarasinianae. III. Verh. Naturf. Ges. Basel 11: 221-258.

Christ, H. 1897. In: F. Reinecke, Die Flora der Samoa-Inseln. Bot. Jahrb. Syst. 23: 237-368.

Christ, H. 1898. Filices Novae. Bull. Herb. Boissier 6: 835-837.

Christ, H. 1901. Reliquiae Weinlandianae. Bull. Herb. Boissier II 1: 445-460.

Christ, H. 1908. Spicilegium Filicum Philippinensium novarum aut imperfecte cognitarum. II. Philipp. J. Sci., Bot. 3: 269-276.

Christ, H. 1909a. Filices. Nova Guinea, Bot. 8.

Christ, H. 1909b. Filices. In: E.A.J. de Wildeman, Etudes de systématique et de géographie botanique sur la flore du Bas-et Moyen-Congo. Ann. Mus. Congo Belge, Bot. 5, 3. Brussels.

Christensen, C. 1906. Index Filicum. Hagerup, Copenhagen.

Christensen, C. 1936. Taxonomic fern studies III. Revision of the genera and species of ferns described by A.J. Cavanilles. Dansk Bot. Ark. 9: 3-32.

Colenso, W. 1888. On newly discovered and imperfectly known ferns of New Zealand, with critical observations. Trans. New Zealand Inst. 20: 212.

Copeland, E.B. 1905. Ferns. Fragm. Fl. Philipp. 3.

Copeland, E.B. 1906. New Philippine Ferns. Philipp. J. Sci. 1, Suppl. 2: 143-166.

Copeland, E. B. 1917. New species and a new genus of Borneo ferns, chiefly from the Kinabalu collections of Mrs. Clemens and Mr. Topping. Philipp. J. Sci., Bot. 12: 45-65.

Copeland, E.B. 1947. Genera Filicum. Chronica Botanica. Waltham, Mass.

Copeland, E.B. 1952. New Philippine Ferns IX. Philipp. J. Sci. 81: 1-47.

Copeland, E.B. 1958. Fern Flora of the Philippines, 1. Institute of Science and Technology, Manila.

Dallwitz, M.J. 1980. A general system for coding taxonomic descriptions. Taxon 29: 41-6.

Dallwitz, M.J., T.A. Paine \& E.J. Zurcher. 1993 onwards. User's guide to the DELTA System: a general system for processing taxonomic descriptions. 4th edition. http://delta-intkey.com

Dallwitz, M.J., T.A. Paine \& E. J. Zurcher. 1999 onwards. User's guide to the DELTA Editor. http://delta-intkey.com

d'Almeida, J.F. R. 1926. A new species of Nephrolepis. J. Indian Bot. Soc. 5: 51-54.

De Vriese, W.H. 1846. Bijdrage tot de kennis der Flora van Sumatra. Ned. Kruidk. Arch. 1: 1-19.

Decaisne, M.J. 1844. Botanique. In: J.V. Jacquemont, Voyage dans l'Indépendant les années 1828-1832. 4. Firmin Didot frères, Paris.

Desvaux, N.A. 1827. Prodrome de la famille des Fougères. Mém Soc. Linn. Paris 6: 213-337.

Don, D. 1825. Prodromus Florae Nepalensis. Gale, London.

Espagnac, H. 1973. Les axes polymorphes de Nephrolepis biserrata. Analyse experimentale du déterminisme de leurs structures. Ann. Sci. Nat., Bot. 12: 223-286.

Fée, A.L.A. 1845. Deuxième mémoire: Histoire des Acrostichées. Veuve Berger-Levrault, Strasbourg.

Fée, A.L.A. 1852. Cinqième mémoire: Genera Filicum. Baillière, Masson \& Veuve Berger-Levrault \& Fils, Paris \& Strasbourg.

Fée, A.L.A. 1857. Neuvième mémoire. Catalogue méthodique des Fougères et des Lycopodiacées du Mexique. Veuve Berger-Levrault \& Fils, Strasbourg.

Fée, A.L.A. 1866. Onzième et dernier mémoire: Histoires des Fougères et des Lycopodiacées des Antilles. Baillière \& Fils, Masson \& Fils \& Veuve Berger-Levrault \& Fils, Paris \& Strasbourg.

Fée, A.L.A. 1869. Cryptogames vasculaires du Brésil. Baillière \& Fils, Masson \& Fils \& Veuve Berger-Levrault \& Fils, Paris \& Strasbourg. 148

Forster, J.G.A. 1786. Florulae insularum australicum prodromus. Diederich, Göttingen.

Gaudichaud-Beaupré, C. 1828. Botanique. In: H.L.C. de Saulces de Freycinet, Voyage autour du Monde. Pillet-ainé, Paris.

Goebel, K.I.E. 1907. Morphologische und biologische Bemerkungen. 17. Nephrolepis duffii. Flora 97: $38-42$. 
Goldmann, J.G. 1843. Filices. Nov. Actorum Acad. Caes. Leop.-Carol. Nat. Cur. Suppl. I.

Heinricher, E. 1907. Zur Kenntnis der Farngattung Nephrolepis. Flora 97: 43-75.

Hohenester, A. \& W. Wells. 1993. Exkursionsflora für die Kanarischen Inseln. Ulmer \& Co., Stuttgart.

Holttum, R.E. 1954. A revised Flora of Malaya II. Ferns. Government Printing Office, Singapore.

Holttum, R.E. 1968. A revised Flora of Malaya II. Ferns. Ed. 2. Government Printing Office, Singapore.

Hooker, W.J. 1846. Species Filicum. 1. Pamplin, London.

Hooker, W.J. 1862. Species Filicum. 4. Pamplin, London.

Hoshizaki, B.J. \& R.C. Moran. 2001. Fern growers manual. Timber Press, Portland, Oregon.

Houttuyn, M. 1783. Natuurlijke Historie II-14. Houttuyn, Amsterdam.

Jenman, G.S. 1896. Synoptical list, with descriptions of the ferns and fern-allies of Jamaica. Bull. Bot. Dept. Jamaica 1 (n.s.).

Jones, D.L.1988. New species from Northern Australia. Austrobaileya 2: 469-480.

Krug, L. 1897. Pteridophyta. Bot. Jahrb. Syst. 24: 77-152.

Kuhn, F. A.M. 1868. Filices Africanae. Engelmann, Leipzig.

Kuhn, F. A.M. 1869. Filices. Ann. Mus. Bot. Lugd.-Bat. 4.

Kunze, G. 1839a. Additamentum enumerationis filicum Mexicanarum. Linnaea 13: 129-153.

Kunze, G. 1839b. Filices in Martii Herbarium Florae Brasiliensis. Flora 1. Beibl.

Kunze, G. 1844. Filices a Leiboldo in Mexico lectae. Linnaea 18: 303-352.

Kunze, G. 1846. In filices Javae Zollingerianas. Bot. Zeitung (Berlin) 4: 460.

Kunze, G. 1848a. In filices Javae Zollingerianas. Bot. Zeitung (Berlin) 6: 236.

Kunze, G. 1848b. Plantae Kegelianae Surinamensis. Filices. Linnaea 21: 201-241.

Kunze, G. 1850. Index Filicum. Linnaea 23: 209-323.

Langsdorff, G.H. \& F. Fischer. 1810. Plantes receuillies pendant le Voyage des Russes autour du Monde. Cotta, Tübingen.

Liew, F. S. 1977. Scanning electron microscopical studies on spores of Pteridophytes. 11. The family Oleandraceae (Oleandra, Nephrolepis and Arthropteris). Gard. Bull. Singapore 30: 101-110.

Link, H.F. 1833. Hortus regius botanicus Berolinensis Vol. 2. Reimer, Berlin.

Linnaeus, C. 1753. Species plantarum. 2. Laurentius Salvius, Stockholm.

Linnaeus, C. 1759. Systema naturae ed. 10, 2. Laurentius Salvius, Stockholm.

Löve, A., D. Löve \& R.E.G. Pichi Sermolli. 1977. Cytotaxonomical atlas of the Pteridophyta. Cramer, Vaduz.

Merrill, E.D. 1918. Species Blancoanae. Bureau of Printing, Manila.

Mettenius, G. 1856. Filices horti botanici Lipsiensis. Voss, Leipzig.

Mettenius, G. 1858. Über einige Farngattungen. IV. Phegopteris u. Aspidium. Abh. Senckenb. Naturf. Ges. 2: 285-420.

Mickel, J.T. \& A.R. Smith. 2004. The Pteridophytes of Mexico. Mem. New York Bot. Gard. The New York Botanical Garden, New York.

Moore, T. 1857. Index Filicum. Pamplin, London.

Moore, T. 1873. New garden plants. Nephrolepis davallioides var. furcans. Gard. Chron. N.S. 13.

Moore, T. 1878a. New garden plants. Nephrolepis pluma. Gard. Chron. N.S. 9: 588.

Moore, T. 1878b. New garden plants. Nephrolepis duffii. Gard. Chron. N.S. 9: 622.

Morton, C.V. 1958. Observations on cultivated ferns. V. The species and forms of Nephrolepis. Amer. Fern J. 48: 18-27.

Morton, C.V. 1974. William Roxburgh's fern types. Contr. US Natl. Herb. 38: 283-396.

Nauman, C.E. 1979a. The genus Nephrolepis in Florida. MSc thesis, Florida Atlantic Univ.

Nauman, C.E. 1979b. A new Nephrolepis hybrid from Florida. Amer. Fern J. 69: 65-70.

Nauman, C.E. 1985. A systematic revision of the neotropical species of Nephrolepis Schott. PhD thesis, The University of Tennessee, Knoxville.

Nauman, C.E. 1992. Nephrolepis. Flora Mesoamericana: 286-289. New York.

Nayar, B.K. \& N. Bajpai. 1978. Morphology in relation to phylogeny of the Davallioid-Oleandroid group of ferns. Phytomorphology 26: 333-354.

Nicolson, D.H. \& F.R. Fosberg. 2003. The Forsters and the Botany of the Second Cook Expedition (1772-1775). T.F. Stuessy, V. Mayer \& E. Hörandl (eds.). Regnum Veg. 
Pichi Sermolli, R.E.G. 1969. Taxonomical notes on Nephrolepis cordifolia (L. ) Presl and related species. Ann. Mus. Civico Storia Nat. Genova 77.

Poiret, J.L.M. 1804. In: J.B. de Lamarck, Encyclopédie Méthodique. Botanique. 5. Pancoucke, Plomteux, Paris, Liège.

Poiret, J.L.M. 1817. In: J.B. de Lamarck, Encyclopédie Méthodique. Botanique. Suppl. 5. Pancoucke, Plomteux, Paris, Liège.

Presl, C.B. 1830. Reliquiae Haenkeanae, 1. Calve, Prague.

Presl, C.B. 1836. Tentamen Pteridographiae. Theophilus Haase, Prague.

Presl, C.B. 1851. Epimeliae Botanicae. Amadeus Haase, Prague.

Proctor, G.R. 1989. Ferns of Puerto Rico and the Virgin Islands. Mem. New York Bot. Garden 53. The New York Botanical Garden, New York.

Raddi, G. 1819. Synopsis Filicum Brasiliensium. Annesii de Nobilibus, Bologna.

Raddi, G. 1825. Plantarum Brasiliensum nova genera. I. Filices. 1. Pezzati, Florence.

Richard, A. 1834. Voyage de découvertes de l' Astrolabe. Botanique. 2. Tastu, Paris.

Rosenstock, E. 1925. Filices novae a cll. Alfred et Curt Brade in Costarica collectae. Feddes Repert. Spec. Nov. Regni Veg. 22.

Roxburgh, W. 1844. In: W. Griffiths, The cryptogamous plants of Dr. Roxburgh. Calcutta J. Nat. Hist. 4: $463-520$

Schkuhr, C. 1804. Vier und zwanzigste Klasse des Linnéischen Pflanzensystems oder kryptogamische Gewächse. Schkuhr, Wittenberg.

Schott, H. 1834. Genera Filicum 1. Wallishauser, Vienna.

Schrader, H.A. 1824. Illustratio Filicum. Goett. Gel. Anz.

Sen, U. \& T. Sen. 1973. Anatomical relationships between the Oleandra and Nephrolepis groups. Bot. J. Linn. Soc., Suppl. 1: 155-172.

Smith, J. 1841. Enumeration Filicum Philippinarum. J. Bot. (Hooker) 3: 393-422.

Smith, J. 1842a. An arrangement and definition of the genera of ferns, with observations on the affinities of each genus. J. Bot. (Hooker) 4: 38-70, 146-198.

Smith, J. 1842b. Pl. 102. In: W.J. Hooker \& F. Bauer, Genera Filicum. Bohn, London.

Smith, J. 1845. Additions to the 'Hortus Kewensis'. Bot. Mag. 72.

Smith, J. 1857. Cultivated ferns. Pamplin, London.

Smith, J. 1866. Ferns: British and foreign. Hardwicke, London.

Smith, J. 1875. Historia Filicum. Macmillan \& Co., London.

Sodiro, A. 1893. Cryptogamae vasculares Quitenses. Typis Universitatis, Quito.

Sprengel, C. 1827. Systema Vegetabilium. Editio decima sexta. 4. Dieterich, Göttingen.

Swartz, O. 1801. Genera et species filicum ordine systematico redactarum. In: H.A. Schrader, J. Bot. 1800 .

Swartz, O. 1806. Synopsis Filicum. Bibliopolii novi academici, Kiel. 44

Sweet, R. 1826. Hortus Brittannicus. 1. Ridgway, London.

Tagawa, M. \& K. Iwatsuki. 1985. Fl. Thailand 3. Pteridophytes. 2. Bangkok.

Tindale, M.D. \& S.K. Roy. 2002. A cytotaxonomic survey of the Pteridophyta of Australia. Austral. Syst. Bot. 15: 839-937.

Trimen, H. 1888. Hermann's Ceylon Herbarium. J. Linn. Soc., Bot. 24: 129-155.

Tryon, A.F. \& B. Lugardon. 1991. Spores of the Pteridophyta. Springer Verlag, New York.

Tryon, R.M. 1962. A note on Nephrolepis cordifolia cv. duffii. Amer. Fern J. 52: 153-155.

Urban, I. 1925. Symbolae antillanae 9-3. Bornträger, Klinksieck, Williams \& Norgate, Leipzig, Paris, London.

Vahl, M. 1807. Eclogae Americanae. Möller \& Filius, Copenhagen.

Van Alderwerelt van Rosenburgh, C.R.W.K. 1908. New or interesting Malayan ferns 2. Bull. Dép. Agric. Indes Néerl. 21: 1-9.

Van Alderwerelt van Rosenburgh, C.R.W.K. 1911. New or interesting Malayan ferns 3. Bull. Jard. Bot. Buitenzorg II, 1: 1-29.

Van Alderwerelt van Rosenburgh, C.R.W.K. 1913. New or interesting Malayan ferns 5. Bull. Jard. Bot. Buitenzorg II, 8: 1-38.

Van Alderwerelt van Rosenburgh, C.R.W.K. 1915. New or interesting Malayan ferns 7. Bull. Jard. Bot. Buitenzorg II, 20: 1-28. 
Van Alderwerelt van Rosenburgh, C.R.W.K. 1917. New or interesting Malayan ferns 9. Bull. Jard. Bot. Buitenzorg II, 24: 1-8.

Van Alderwerelt van Rosenburgh, C.R.W.K. 1918. New or interesting Malayan ferns 10. Bull. Jard. Bot. Buitenzorg II, 28: 1-56.

Van Alderwerelt van Rosenburgh, C.R.W.K. 1924. Pteridophyta. Nova Guinea, Bot. 14: 1-72.

Verdcourt, B. 1996. Proposals to conserve the name Polypodium cordifolium with a conserved type, and to reject P. auriculatum in order to stabilize nomenclature in Nephrolepis (Oleandraceae or Nephrolepidaceae). Taxon 45: 539-541.

Verdcourt, B. 2001. Flora of Tropical East Africa. Oleandraceae. Balkema, Rotterdam.

Wagner Jr., W.H., F.S. Wagner, D.D. Palmer \& R.W. Hobdy. 1999. Taxonomic notes on the Pteridophytes of Hawaii-II. Contr. Univ. Michigan Herb. 22: 135-187.

Wawra, H. 1866. Botanische Ergebnisse. Carl Gerold's Sohn, Vienna.

Weber, E. 2004. Invasive plant species of the world. Wallingford (UK), Cambridge, MA, CABI Publishing.

Wikström, J.E. 1826. Nya eller mindre kanda arter af Ormbunkar (Filices). Vet. Ak. Handl. 1825: 434.

Willdenow, K.L. 1810. Species plantarum 5-1. Nauk, Berlin.

\section{INDEX}

Numbers refer to the species numbers given in the text. Synonyms are in italics. New species are in bold. cult $=$ cultivars and monstrosities; excl. $=$ excluded.

Arthropteris obliterata (R.Br.) J.Sm. 14

Aspidium acuminatum Willd. 3

acutum Schkuhr 3

bidentatum Spreng. 3

biserratum (Sw.) Sw. 3

cordifolium (L.) Sw. 5

davallioides Sw. 7

eminens Wikstr. 18

ensifolium Schkuhr 3

exaltatum (L.) Sw. 9

floccigerum Blume 4

gibbosum Willd. 3

hirsutulum (G. Forst.) Sw. 12

hoffmanseggi (Willd.) Poir. 18

imbricatum Spreng. 5

obliteratum Spreng. 14

obtusifolium Willd. 17

paludosum Raddi 3

paraense Willd. 3

pectinatum Willd. 15

pendulum Raddi 16

pilosum Langsd. \& Fisch. 12

punctulatum Sw. 3

rufescens (Schrad.) Kunze 3

schkuhrii Blume 4

sesquipedale Willd. 18

splendens Willd. 3

tuberosum Bory 5

undulatum Afzel. 19

Asplenium sp. excl.

Davallia multiflora Roxb. 4
Dicksonia abrupta Bory 1 nephrolepioides $\mathrm{H}$. Christ 8

Diellia browni E. D. Br. \& F. Br. 2

Hypopeltis amygdalina Bory 3 biserrata (Sw.) Bory 3 exaltata (L.) Bory 9 palmoides (Schkuhr) Bory 3

Isoloma lanuginosa J.Sm. 2

Lepidonevron acuminatum (Willd.) Fée 3 biauritum Fée 3

bidentatum (Spreng.) Fée 3

biserratum (Sw.) Fée 3

hirsutulum (G. Forst.) Fée 12

punctulatum (Sw.) Fée 3

rufescens (Schrad.) Fée 3

sesquipedale (Willd.) Fée 18

volubile Fée 17

Leptopleuria C. Presl [p. 286]

abrupta (Bory) C. Presl 1

Lindsaya acutifolia Desv. 2 lanuginosa (J.Sm.) Hook. 2

Nephrodium acuminatum (Willd.) C. Presl 3

acutum (Schkuhr) C. Presl 3

bidentatum (Spreng.) C. Presl 3

biserratum (Sw.) Desv. 3

brownii Desv. 4

crenatum Desv. 16

davallioides (Sw.) Desv. 7

deparioides Bory 7

edule D. Don 5

exaltatum (L.) R.Br. 9 


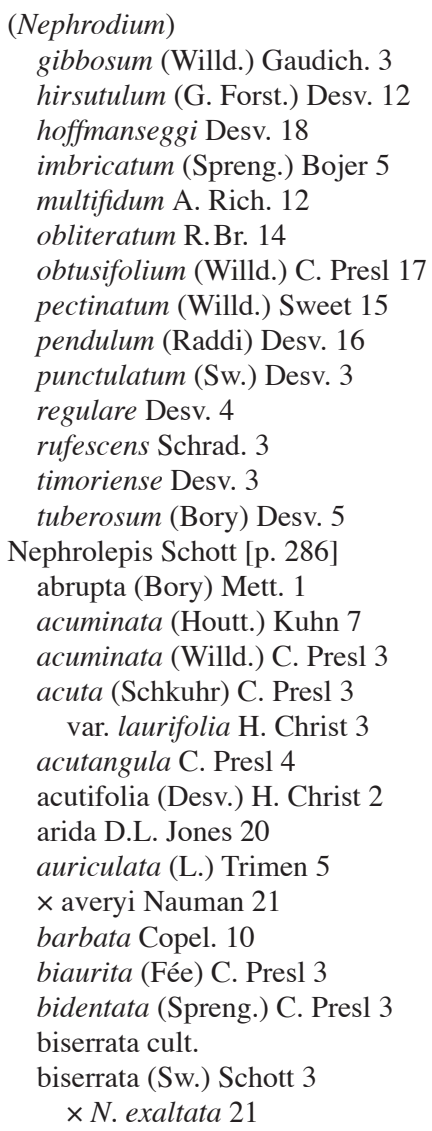

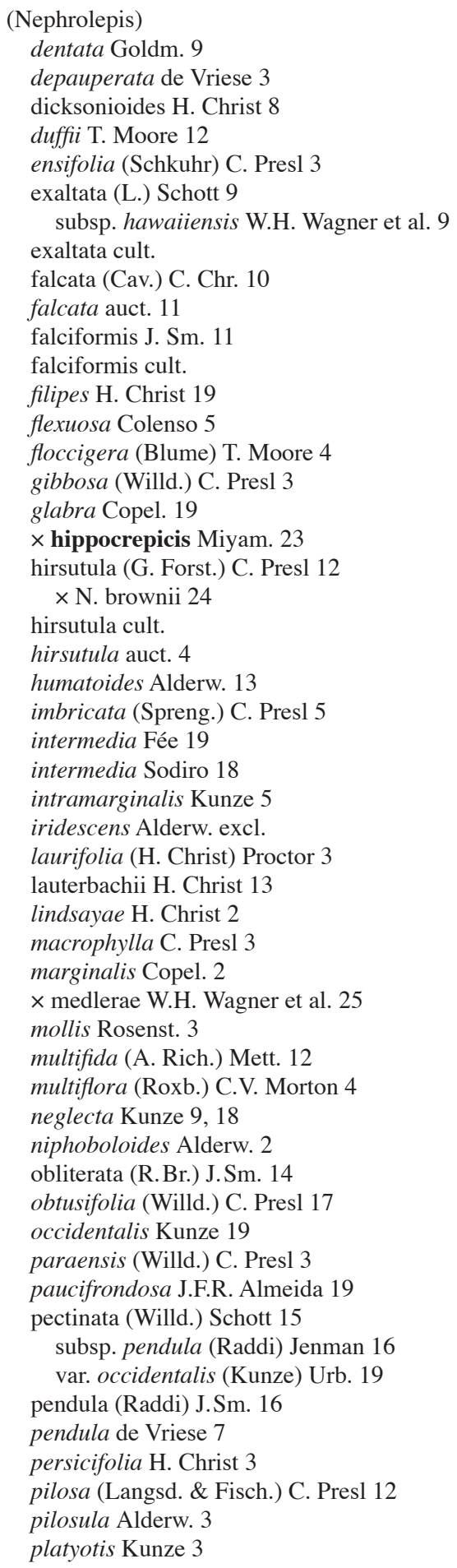


(Nephrolepis)

pluma $\mathrm{T}$. Moore 19

$\times$ pseudobiserrata Miyam. 26

pubescens Copel. 4

pumicicola $\mathrm{F}$. Ballard 5c

punctulata (Poir.) C. Presl 3

radicans (Burm.f.) Kuhn 17

rhizodes Kunze 5

rivularis (Vahl) Mett. ex Krug 18

rosenstockii Brause 8

rufescens (Schrad.) Wawra 3

saligna Carruth. 14

schkuhrii Fée

var. minor Fée 15

schlechteri Brause 6

serrata Alderw. 7

sesquipedalis (Willd.) C. Presl 18

splendens (Willd.) C. Presl 3

thomsonii Alderw. 11

tomentosa Alderw. 4

tuberosa (Bory) C. Presl 5

var. delicatula Hook. 19

var. pendula (Raddi) Hook. 16

var. undulata (Afzel.) Kuhn 19

\author{
(Nephrolepis) \\ undulata (Afzel.) J.Sm. 19 \\ var. delicatula (M.J. Decne.) Verdc. 19 \\ var. undulata (Afzel.) Verdc. 19 \\ valida Kunze 18 \\ volubilis (Fée) J.Sm. 17 \\ zollingeriana de Vriese 3 \\ Ophioglossum acuminatum Houtt. 7 \\ Polypodium auriculatum L. 5 \\ cordifolium L. 5 \\ exaltatum L. 9 \\ flagelliferum Roxb. 3 \\ hirsutulum G. Forst. 12 \\ palmoides Bory 3 \\ punctulatum Poir. 3 \\ radicans Burm.f. 17 \\ rivulare Vahl 18 \\ Polystichum hirsutulum (G. Forst.) Bernh. 12 \\ Pteris signata Merr. 3 \\ Tectaria falcata Cav. 10 \\ fraxinea Cav. 3
}

